Florida International University FIU Digital Commons

$11-13-2007$

\title{
Effects of a switchgrass buffer strip on soil microorganisms near a field applied with endosulfan
}

Cristina Clark-Cuadrado

Florida International University

DOI: $10.25148 /$ etd.FI14060849

Follow this and additional works at: https://digitalcommons.fiu.edu/etd

Part of the Environmental Sciences Commons, and the Environmental Studies Commons

\section{Recommended Citation}

Clark-Cuadrado, Cristina, "Effects of a switchgrass buffer strip on soil microorganisms near a field applied with endosulfan" (2007). FIU Electronic Theses and Dissertations. 2379.

https://digitalcommons.fiu.edu/etd/2379 


\section{FLORIDA INTERNATIONAL UNIVERSITY}

Miami, Florida

EFFECTS OF A SWITCHGRASS BUFFER STRIP ON SOIL MICROORGANISMS NEAR A FIELD APPLIED WITH ENDOSULFAN

A thesis submitted in partial fulfillment of the requirements for the degree of MASTER OF SCIENCE in

ENVIRONMENTAL STUDIES

by

Cristina Clark-Cuadrado 
To: Interim Dean Mark Szuchman

College of Arts and Sciences

This thesis, written by Cristina Clark-Cuadrado, and entitled Effects of a Switchgrass Buffer Strip on Soil Microorganisms near a Field Applied with Endosulfan, having been approved in respect to style and intellectual content, is referred to you for judgment.

We have read this thesis and recommend that it be approved.

Kevin E. O'Shea

Stewart T. Reed

Krishnaswamy Jayachandran, Major P'rofessor

Date of Defense: November 13, 2007

The thesis of Cristina Clark-Cuadrado is approved.

Interim Dean Mark Szuchman College of Arts and Sciences

Dean George Walker University Graduate School

Florida International University, 2007 


\section{ACKNOWLEDGMENTS}

I wish to thank the members of my committee for their assistance and advice in accomplishing this project, Dr. Mahadev Bhat for his support and guidance throughout my graduate career, and the USDA Subtropical Research Station for the space, time, and equipment provided for my research. A special thanks to Mark Sullivan, for his knowledge in pesticide application and help to create the test plots, and to Chris Dunn and Ric Joseph for their never-ending help in the field and in the lab.

I also want to thank Dr. Paulette Johnson and Jennifer Reixach for their statistical assistance; Dr. Jennifer Richards for her help and knowledge in plant identification; Dr. Kateel Shetty for his help in microbial analyses; and Michael and Kevin Clark-Cuadrado, for their help with soil analyses.

A special acknowledgement to USDA/CSREES under the 2005 Hispanic Serving Institute Higher Education Grants Program (Award \# 2005-38422-15940) for funding my research. 
ABSTRACT OF THE THESIS

EFFECTS OF A SWITCHGRASS BUFFER STRIP ON SOIL MICROORGANISMS

NEAR A FIELD APPLIED WITH ENDOSULFAN

by

\section{Cristina Clark-Cuadrado}

Florida International University, 2007

Miami, Florida

Professor Krishnaswamy Jayachandran, Major Professor

A field study to determine the effects of a switchgrass buffer strip (SBS) on soil microorganisms near a field applied with endosulfan was carried out. Soil samples were taken from a SBS and bare soil area downslope from a field applied with endosulfan at different distances, days, and two seasons (wet and dry). Soil samples were analyzed for endosulfan, soil fungi, and bacteria. Analysis of endosulfan concentrations was done by reversed-phase liquid chromatography. No endosulfan runoff was detected by this method. Analysis of suil fungi and bacteria was done by fungal and bacterial enumeration by plate count method on rose bengal agar and tryptic soy agar, respectively.

Soil fungi and bacteria were higher in the SBS than in the bare soil area. Also, soil bacteria was higher during the wet season than during the dry season. The opposite trend was observed for soil fungi. 
I. INTRODUCTION

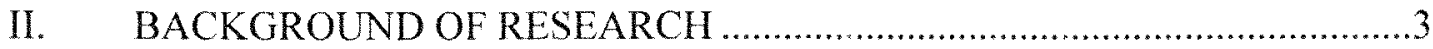

The Use of Pesticides in Conventional Agriculture ...........................................

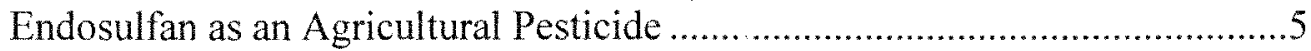

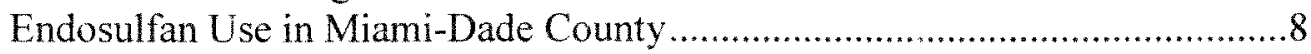

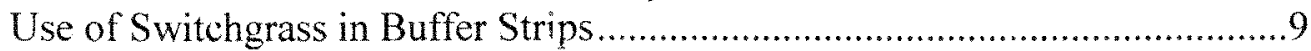

Soil Microorganisms in Agricultural Lands ..............................................12

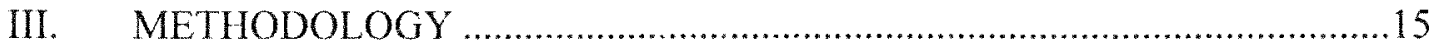

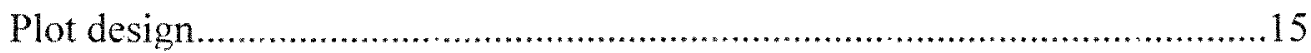

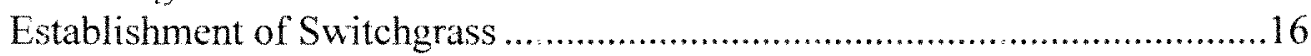

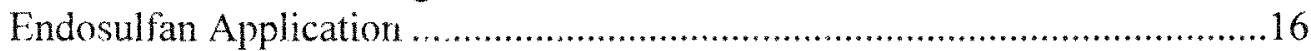

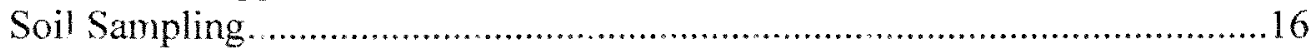

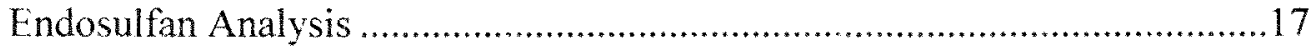

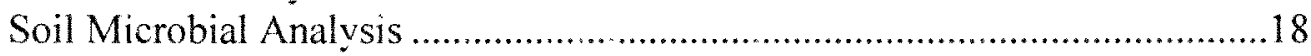

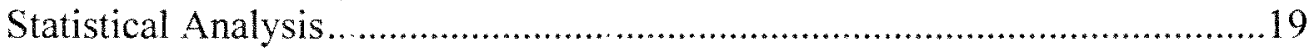

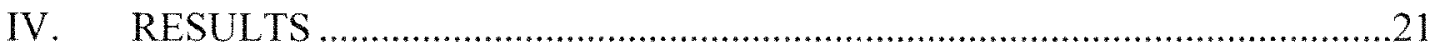

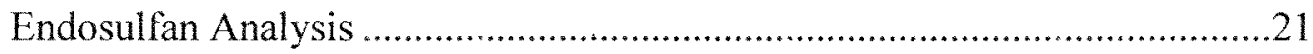

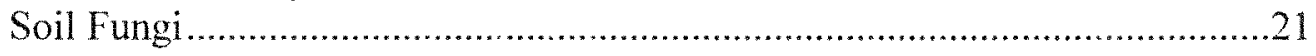

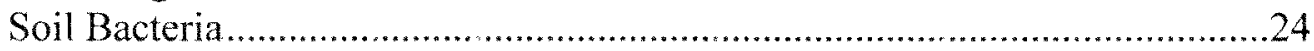

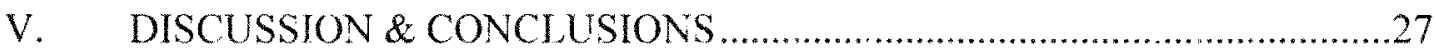

Use of Switchgrass Buffer Strips in South Florida .......................................27

Effects of Endosulfan Runoff on Soil Fungi and Bacteria ............................28

Effects of Switchgrass Buffer Strip on Soil Fungi and Bacteria ......................30

Seasonal Effects on Soil Fungi and Bacteria .................................................31

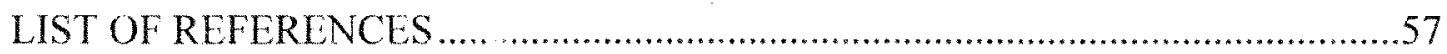


TABLE

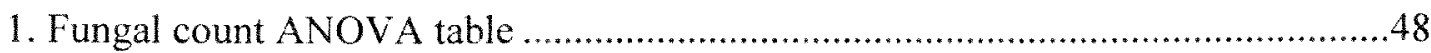

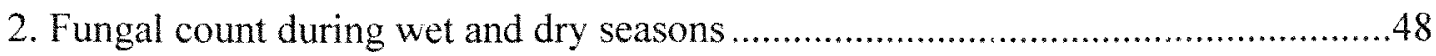

3. Fungal count for bare soil and switchgrass buffer strip treatments .......................48

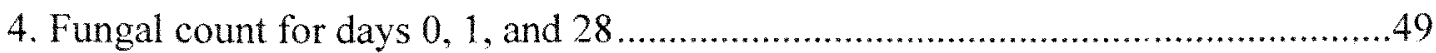

5. Pairwise comparisons between seasons and plant covers for fungal count ............49

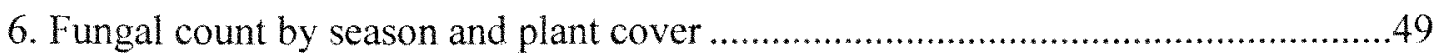

7. Fungal counts for bare soil and switchgrass buffer strip treatments,

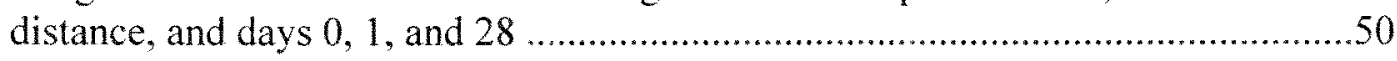

8. Pairwise comparisons between treatments and distance for days 0,1 ,

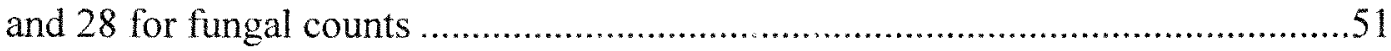

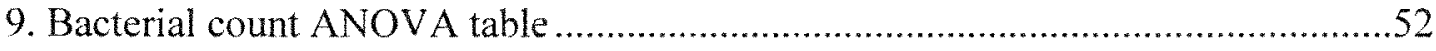

10. Bacterial count during wet and dry seasons .................................................52

11. Bacterial count for bare soil and switchgrass buffer strip treatments ...................52

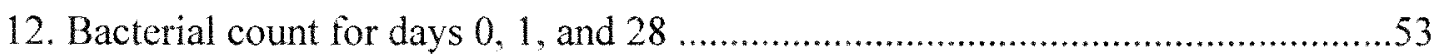

13. Pairwise comparisons between seasons and plant covers for bacterial counts ......53

14. Bacterial count by season and plant cover ....................................................53

15. Bacterial count for bare soil and switchgrass buffer strip treatments,

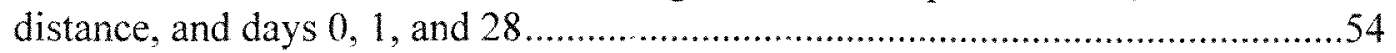

16. Pairwise comparisons between treatments and distance for days 0,1 ,

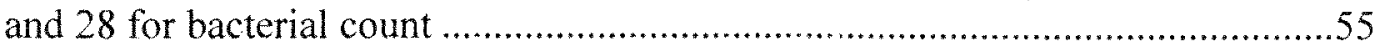

17. Pairwise comparisons between days and treatments for distances 0.3 and $0.9 \mathrm{~m}$ for fungal count 
18. Pairwise comparisons between days and treatments for distances 0.3 and

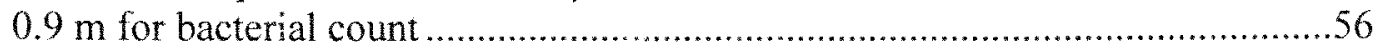




\section{LIST OF FIGURES}

FIGURE

1. Molecular structure, molar mass, solubility in water, and CAS registry number of endosulfan.....

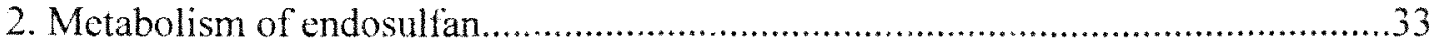

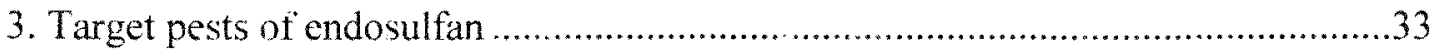

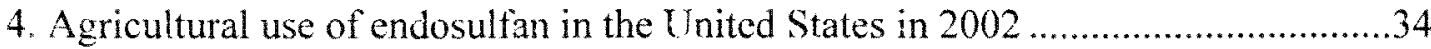

5. Seasonal microbial activity in a temperate grassland or cropland ...........................35

6. Field plot layout for switchgrass buffer strip study ...........................................36

7. Test plot with the switchgrass buffer strip and strip of bare soil .............................37

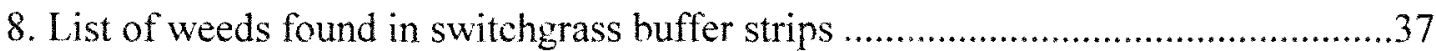

9. Application of endosulfan with a backpack sprayer and hand wand

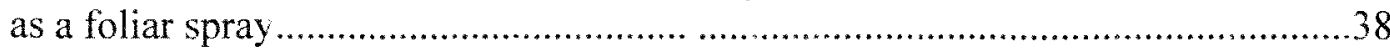

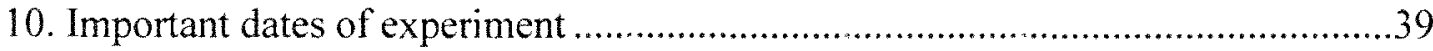

11. Comparison of fungal count for bare soil and switchgrass treatments

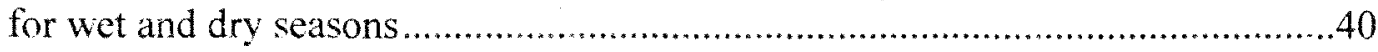

12. Fungal count by day, distance, and plant cover ..................................................

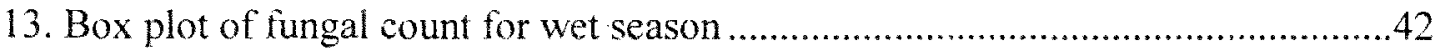

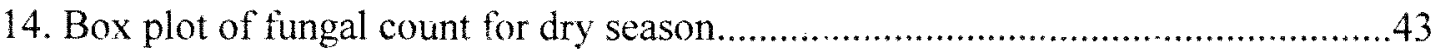

15. Comparison of bacterial count for bare soil and switchgrass treatments

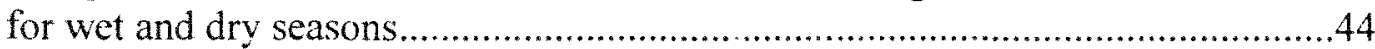

16. Bacterial count by day, distance, and plant cover..............................................45

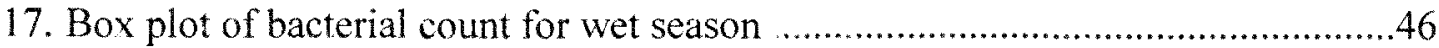

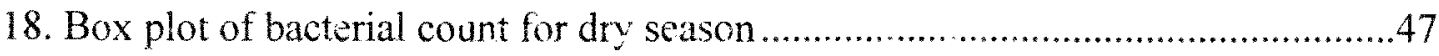




\section{CHAPTER I \\ INTRODUCTION}

Information on the effectiveness of buffer strips for the reduction of endosulfan runoff from agricultural fields is limited. Though studies have been conducted in the greenhouse (Mersie et al., 2005), field studies are needed to document the fate and transport of endosulfan and its effects on soil biology. Modeling the fate and transport of endosulfan through a vegetative buffer strip is needed to understand, predict, and prevent endosulfan contamination of waterways, soils, and ecosystems. Furthermore, few studies have evaluated the potential of switchgrass to reduce endosulfan pollution and improve soil quality when used as a buffer strip.

Soil bacteria and fungi play a significant role in agricultural soils. Pathogenic soil bacteria and fungi receive significant attention from farmers and soil conservationists due to their negative effects on agricultural productivity. However, most soil bacteria and fungi are beneficial to soil, plant, and the environment. Bacteria and fungi play vital roles in agricultural soils and natural environments, such as their effect on organic matter turnover and nutrient cycling (Wood, 1989). There is limited information on the effects of endosulfan on soil bacteria and fungi. Information on the effects of endosulfan runoff passing through a switchgrass filter strip can help agricultural landowners manage their endosulfan applications and design of filter strips to prevent contamination of adjacent natural areas. Furthermore, this information can give farmers insight on possible secondary effects of endosulfan application on soil bacteria and fungi, helping them make more educated decisions about managing soil quality. 
The objectives of this study were to determine the effectiveness of a switchgrass buffer strip in reducing endosulfan runoff and to study the effects of endosulfan on soil microbial populations. Previous studies indicate that a switchgrass buffer strip will be more successful in abating endosulfan runoff than a bare ground soil (Lee et al., 1998). However, buffer strips may also increase infiltration, thus causing problems for groundwater (USDA, 2002). The effects of endosulfan on soil bacterial and fungal populations were also studied, as well as the effects of a switchgrass buffer strip on soil bacterial and fungal populations adjacent to a field applied with endosulfan. Higher bacterial and fungal populations were expected in the soil of the switchgrass buffer strip than in the bare soil strip. In addition, bacteria and fungi will increase with the distance from the point of endosulfan application. 


\section{CHAPTER II}

\section{BACKGROUND OF RESEARCH}

The Use of Pesticides in Conventional Agriculture

Conventional agriculture has often been blamed for the overall decline of ecosystem health. Since agricultural areas cannot be separated from the surrounding ecosystems, natural resource management must include agricultural as well as natural areas for healthier agroecosystems. Agricultural runoff frequently carries pesticides, heavy metals, and nutrients that are harmful to beneficial insects and animals, as well as endanger human health, fisheries, and tourism (UNEP, 1999). Some pesticides are lost to the atmosphere through volatilization, however most applied pesticides remain in the soil (Wright et al., 1993). Once in the environment, pesticides may be absorbed by plants and other organisms, chemically decomposed, volatilized, adsorbed onto soil particles, subjected to runoff, and leached through the soil profile (Rao et al. 2006). Urban development and agricultural operations have decreased the amount of vegetated areas along bodies of water able to absorb and stop or reduce the movement of pollutants before reaching the water bodies.

Knowledge of the fate and transport of pesticides is essential in reducing off-site movement of these contaminants. Although pesticides may enter the environment from point sources (such as spills or improper disposal), nonpoint sources (such as agriculture) are the main contributors of pesticides into natural environments (EPA, 1992). The main properties of a pesticide affect its behavior after application are solubility, adhesion, degradation, and persistence. 
Solubility: Pesticides that are soluble in water are likely to leach through the soil and contaminate groundwater, or flow with surface water and contaminate streams, rivers, lakes, or other bodies of water. In general, water solubilities of pesticides higher than 30 parts per million ( $\mathrm{ppm}$ ) have an increased tendency to leach down through the soil profile (Landon et al., 1994).

Adhesion: Pesticides often adhere to soil particles or organic matter through adsorption. Pesticides that adhere to soil particles have a lower leaching potential than water-soluble pesticides (Buttler et al., 2003). However, studies have shown that pesticide molecules that tightly adhere to soil particles may not be easily broken down by microorganisms (Landon et al. 1994) and may therefore persist longer in the environment.

Degradation: Chemical reactions break down or degrade pesticides through time. Break down may occur through microbial degradation, chemical degradation (by chemical reactions not involving microorganisms), or photodegradation (light mediated chemical reactions). Degradation of a pesticide does not signify that the pesticide is less harmful. Often, the products of the degradation of pesticides are as or more harmful than the original pesticide and may persist longer in the environment. For example, research conducted by the United States Geological Survey (USGS) and Southern Illinois University scientists indicates that the metabolites of the pesticides chlorpyrifos and malathion are about 100 times more toxic than the parent compounds (Sparling et al., 2007).

Persistence: Persistence describes a pesticide's continuing existence in the environment. Persistence is measured by the amount of time it takes for half of the active 
ingredient of the pesticide to degrade, otherwise known as its half-life. The half-life of a pesticide is dependent on the nature of the chemical itself and several environmental factors, such as soil type, temperature, light, moisture, microorganisms, etc. Persistent pesticides, including endosulfan, are considered to last in the environment longer than 6 months (Moriarty, 1975).

\section{Endosulfan as an Agricultural Pesticide}

The chemical commonly called endosulfan was first used as a wood preservative; however, it was registered as a pesticide in 1954 to control agricultural pests such as aphids, spittlebugs, and whiteflies. Endosulfan is a restricted-use pesticide classified as a chlorinated hydrocarbon insecticide and acaricide. Chlorinated hydrocarbons, in particular organochlorine insecticides are considered to be persistent in the environment (EPA, 2002) and have a high potential to bioaccumulate in organisms. Their persistence and the fact that they require small amounts of applied chemical to achieve their goal keeps application costs low. Some well-known organochlorine insecticides are DDT, aldrin, dieldrin, heptachlor, chlordane, telodrin, difocol, and lindane (IUPAC, 1972). Endosulfan, like most other organochlorine insecticides, is banned in several countries due to its persistence in the environment and its toxicity to humans and animals (Kegley et al., 2007). However, endosulfan is not banned in the United States and is widely used for agricultural purposes.

Endosulfan has undergone the United States Environmental Protection Agency (EPA) re-registration process several times with amendments to the label due to environmental and human health concerns and lack of data on the effects and behavior of endosulfan on several organisms (EPA, 2002). In 2000, residential use of endosulfan in 
the United States was prohibited due to health concerns. The last re-registration of endosulfan under the EPA was in 2002 (EPA, 2002). Earlier in 2007, the European Commission proposed to include endosulfan in the list of Persitent Organic Pollutants banned under the Stockholm Convention (PANNA, 2007).

The chemical name for endosulfan is 6,7,8,9,10-hexachloro-1,5,5a,6,9,9ahexahydro-6,9-methano-2,4,3-benzodioxathiepin-3-oxide, and its formula is $\mathrm{C}_{9} \mathrm{H}_{6} \mathrm{CL}_{6} \mathrm{O}_{3} \mathrm{~S}$ (Figure 1). Commercial endosulfan is composed of two isomers: 70 percent $\alpha$-endosulfan and 30 percent $\beta$-endosulfan, which have different properties (Kegley et al., 2007). The $\alpha$-isomer is more toxic, more volatile, and less water soluble than the $\beta$ isomer. However, the $\beta$-endosulfan isomer is more persistent in the environment than the $\alpha$-isomer (EPA, 2002). Both endosulfan isomers are metabolized initially to endosulfansulfate via oxidation and hydrolysis (Sutherland et al., 2000). Endosulfan sulfate is even more persistent than the parent material (Kwon et al., 2005). Endosulfan sulfate then metabolizes into endosulfan-diol, endosulfan hydroxyether, and endosulfan-lactone. These changes are shown in Figure 2. The toxicity of endosulfan-sulfate to mammals is about the same as for the parent compound itself, whereas the diol, the hydroxyether, and the lactone can be considered nontoxic (IUPAC, 1972). These nontoxic metabolytes have a lethal dose $\left(L D_{50}\right)$ ranging from $150-15000 \mathrm{mg} / \mathrm{kg}$ in rats, whereas the toxic endosulfan isomers have an $\mathrm{LD}_{50}$ of 18 to $160 \mathrm{mg} / \mathrm{kg}$ in rats (EXTOXNET, 1996). For the purpose of this study, only toxic forms of endosulfan will be of interest. The molecular structure, molar mass, and solubility in water of the toxic forms of endosulfan can be found in Figure 1. The half life of commercial endosulfan and its metabolite endosulfan-sulfate ranges from 9 months to 6 years in soil (EPA, 2002). Endosulfan has a high affinity to 
sorb to soil and is likely to be associated predominantly with suspended particles in runoff (EPA, 2002).

Endosulfan is commonly sold commercially under the trade names Thiodan $\mathbb{R}$, Phaser $(\mathbb{B}$, and Thionex $(\mathbb{B}$. Technical grade endosulfan is sold as 95 percent active ingredient (a.i.). Endosulfan is also sold commercially as a 9 to 34 percent a.i. emulsifiable concentrate, and a 1 to 50 percent a.i. wettable powder found in wettable bags. It can be applied by groundboom sprayer, fixed-wing aircraft, chemigation, airblast sprayer, rights of way sprayer, low and high pressure handwand sprayer, backpack sprayer, and dip treatment (EPA, 2002). A 300- foot minimum spray drift buffer for aerial applications between the treated crop and environmentally sensitive areas or waterways is specified on the label.

Endosulfan is an endocrine disruptor and a neurotoxin that acts as a contact and stomach poison to several agricultural pests (EPA, 2002). Figure 3 includes a list of endosulfan's target pests. It can be used on a wide variety of vegetables, fruits, cereals, ornamental shrubs, trees, vines, and herbaceous plants. Its main use in the United States is on cotton, tomatoes, potatoes, apples, tobacco, pears, cucumbers, lettuce, green beans, and squash (EPA, 2002). Endosulfan is a very persistent chemical that may stay in the environment for lengthy periods particularly in acidic media (EPA, 2002).

Endosulfan has been found in areas that have never had endosulfan application, such as the Arctic region and several National Parks. Endosulfan is problematic for fish, amphibians, birds, and mammals. In fact, "Endosulfan was the most frequently detected insecticide in tadpole and adult from tissues in a California study" (EPA, 2002). It has been blamed for over 91 incidents of fish kills and damage to aquatic and semi-aquatic 
organisms in the United States since 1971, mostly in California, South Carolina, and Louisiana. About 32 percent of these incidents were directly attributable to runoff (EPA, 2002). Endosulfan has also caused fish kills on five continents (EPA, 2002) and deformations, abnormalities, and death in animals and humans due to its application near them. Since endosulfan is highly toxic and has a high potential to bioaccumulate in fish and other animals, this problem is of great concern.

Endosulfan can be absorbed through the skin. In humans and mammals endosulfan affects the nervous system. Symptoms include imbalance, difficulty breathing, vomiting, convulsions, and loss of consciousness. The kidneys, liver, blood, and parathyroid gland are the organs most likely to be affected (EXTOXNET, 1996). Studies with cows, sheep, and pigs also show that endosulfan causes temporary blindness (for about a month) (EXTOXNET, 1996). Animals should not be allowed to graze on pasture that has been contaminated with endosulfan. Applicators and handlers of endosulfan, though, are at most risk and should be particularly careful with the pesticide. Endosulfan Use in Miami-Dade County

Miami-Dade County is a major agricultural producer. It is the county in Florida that has the second highest market value of agricultural products sold (NASS, 2004). The use of chemicals for agricultural production in Miami-Dade can negatively impact the soil, water, air and other natural resources of the area. In 2002, 10 million pounds of agrochemicals were used and recorded (Hapeman et al., 2002). The climate in MiamiDade, being warm most of the year, increases the amount of pests and weeds and the spread of pathogens in agricultural operations. Therefore, the amount of chemicals needed for high agricultural output is great. Heavy and frequent rainstorm events between 
May and October cause pesticides and other agrochemicals to leach through or run off the surface of treated fields. South Florida's expansive aquatic, amphibian, and avian fauna (both permanent and migratory) are particularly at high risk to endosulfan poisoning. Several agrochemicals including endosulfan have already been found in South Florida's canals, which drain into the Florida Bay, the Atlantic Ocean, and the Gulf of Mexico (Harman Fetcho, 2005). Agrochemicals can also easily enter the Everglades National Park due to its proximity to these agricultural lands. In Miami-Dade County, an annual average of over 45.5 grams a.i. of endosulfan per square kilometer of agricultural land is used, making Miami-Dade County one of the heaviest users of this pesticide in the country (Figure 4). In Miami-Dade County, most of endosulfan use is due in part by the continuous and heavy agricultural production of tomatoes, green beans, and squash. Use of Switchgrass in Buffer Strips

Pesticides that bind to soil particles through adsorption, such as endosulfan, are transported with soil particles suspended in runoff (Buttler et al., 2003). Deposition of contaminated sediment in a body of water can lead to persistent environmental and health problems since the pollutant could be released slowly as the sediment gets stirred in the water. Vegetative filters, or buffer strips, are natural or manmade strips of herbaceous vegetation between disturbed areas, such as cropland, and areas that are environmentally sensitive, such as a river or a lake. Among other things, they are used to improve water quality by reducing sediment runoff and transport of nutrients, animal wastes, and pesticides from agricultural lands to water bodies.

It is very important to have a shallow sheet flow through the filter strip for it to provide the benefits sought. Rills and gullies must be repaired immediately to prevent 
areas of concentrated flow. The vegetation in buffer strips must also be mowed on a regular basis to promote thick vegetation (USDA, 2002). Trapped sediment needs be removed or redistributed as needed to prevent the formation of rills and gullies (USDA, 2002).

The conditions in vegetative filter strips, both biological and physical factors, favor increased water infiltration and therefore the reduction of dissolved contaminants carried in runoff (USDA, 2002). Studies indicate that water infiltration under buffers can be as much as five times higher than in adjacent cultivated fields and pastures (USDA, 2002). This increase in soil infiltration is caused by several factors: The extensive root system in filter strips increases biological activity by supplying an energy source to soil organisms. These organisms, in turn, degrade pesticides and other contaminants. The increased organic matter found in filter strips improves soil aggregation and slows down runoff, reducing erosion of contaminated particles .

Vegetative filter strips have other benefits aside from their potential reduction of contaminants in runoff. They can serve as habitat and food for beneficial insects and wildlife, or as a corridor between two natural areas of suitable habitat for many species, increasing the animal's chances of finding food, water, shelter, and a suitable climate (USDA, 2002).

Also, erosion control is another benefit of vegetative filter strips. Eroding banks can remove land, reducing its size and become sediment in the water. Soil particles suspended in the water damage aquatic habitat, degrade drinking water quality, and reduce water holding capacity in wetlands, lakes, and reservoirs (Schultz, 1995). Eroding 
banks are also dangerous to farmers. Filter strips can act as a natural barrier, keeping equipment from rolling on steep ditches or riverbanks.

To avoid damage to the vegetative filter strip, it is best to use vegetation that is resistant to the herbicides and other pesticides that will be applied upslope. Fescue is the most commonly used grass for filter strips (Blanco-Canqui et al., 2005), although canarygrass, and bermudagrass are also commonly used. Desirable grasses, though, will vary with the location and specific purpose of the filter strip. Native, tall, erect, stiffstemmed perennial grasses that produce dense vegetation and have extensive root systems are preferred and work best for filter strips.

Switchgrass (Panicum virgatum L.), is a native warm-season tall grass that tolerates drought, very wet conditions, and soils low in nutrients. It produces high yields with very low applications, if any, of fertilizer. Switchgrass also spreads through both seeds and rhizomes, forming a thick sod. It has recently received attention as a grass for vegetative buffer strips and has proven to work better than other grasses in various studies. Blanco-Canqui et al. (2005), for example, found that switchgrass planted along a fescue vegetative buffer strip was more effective in reducing runoff than an only-fescue buffer strip of the same width. Mersie et al. (2005) found that a 19-inch wide strip of switchgrass reduced runoff from sediment coarser than $0.125 \mathrm{~mm}$ (fine sands and coarser) by 90 percent. In addition, switchgrass is adapted to a variety of climates (from warm, southern climates to colder, northern climates) and tolerant of triazine herbicides that may be used upslope in the field. Its use can prove useful throughout most of the United States. 
Attention needs to be given to soil microorganisms in agricultural lands since they are an integral part in maintaining productive soils. Soil microorganisms decompose organic compounds (including some pesticides), cycle nutrients making them available to plants and other organisms, sequester carbon, suppress diseases malignant to agricultural crops, and play an integral role in water dynamics by creating soil aggregates (Wood, 1989).

Bacteria and fungi are the smallest of soil microorganisms, with a cell width of less than $1 \mu \mathrm{m}$ and $10 \mu \mathrm{m}$, respectively (Wood, 1989). However, they are the most abundant organisms in the majority of soils. On average, there are between $10^{6}$ and $10^{9}$ bacteria in a gram of soil (Wood, 1989), translating into about one ton of bacterial biomass in an acre of soil. Fungi are also found in large quantities in the soil. In agricultural lands, there can be several yards of fungi in one gram of soil, tens to hundreds of yards in one gram of prairie soil, and one to forty miles in one gram of coniferous forest soil (Tugel et al., 2000).

Both bacteria and fungi have similar roles: they break down residue and cycle nutrients for plant use, produce compounds or have fungal hyphae that help create soil aggregates, and protect plant roots from disease-causing organisms by competing with them (Alexander, 1977). Since they are mostly aerobic, bacteria and fungi are present in higher abundance in the top $10 \mathrm{~cm}$ of the soil surface (Alexander, 1977) and most active between Spring and Fall, after the last frost and before the first frost of the year (Tugel et al., 2000). Figure 5 indicates seasonal bacterial and fungal activity in grasslands or croplands. A study by Pietikäinen et al. (2005) also indicated that fungi and bacteria had 
different temperature requirements: While fungal and bacterial growth rates had optimum temperatures of around $25-30^{\circ} \mathrm{C}$, fungi was more adapted to lower temperatures and bacteria was more adapted to higher temperatures. This temperature effect could have implications for the warm Miami-Dade soils.

Fungi can live on the hard-to-metabolize organic material, such as woody debris. They are more dominant in acidic soils, such as those found in woodlands. Under dry conditions, fungi have an advantage over bacteria since they can use their hyphae to get to the moisture pockets in the soil (Bardgett, 2005).

Bacteria are more numerous in areas where substrates that are easily metabolized exist, for example in the rhizosphere and around young plant residue (Alexander, 1977). They cannot move great distances and require moisture for reproduction and metabolism. In very dry or in anaerobic conditions, such as when the soil floods or becomes compacted, some bacteria can become dormant or die (Alexander, 1977). Highly acid or alkaline conditions tend to inhibit many common bacteria (Wood, 1989). The optimum $\mathrm{pH}$ for most species is near neutral. One of the most important features of bacteria as a group is their biochemical versatility. Some species of bacteria, like Pseudomonas sp., is able to metabolize a wide range of chemicals including pesticides. Thiobacillus ferrooxidans gets its energy from the oxidation of reduced sulfur compounds and ferrous ions (Wood, 1989). Several studies have successfully degraded endosulfan with the use of bacteria. Sutherland et al. (2000), for example, used a Mycobacterium strain to degrade technical endosulfan. Kwon et al. (2005) used Klebsiella pneumoniae to degrade endosulfan without formation of the toxic metabolite, endosulfan sulfate. Kumar et al. 
(2006) have been able to degrade endosulfan with the use of Stenotrophomonas maltophilia and Rhodococcus erythropolis. 
CHAPTER III

\section{METHODOLOGY}

The procedures below were repeated twice: once during the wet season (June to October) and again during the dry season (November to March). For the purpose of this study, the wet season will be identified as WS and the dry season as DS.

\section{Plot design}

The plots are located in an open area at the USDA, Subtropical Horticulture Research Station in Miami, FL containing a Pennsuco Marl (coarse-silty, carbonatic, hyperthermic typic fluvaquent) soil. A $10 \times 15 \mathrm{~m}$ section of land was cleared and graded to provide a 3 to $5^{\circ}$ slope. The slope was created to produce runoff and move soil downslope (Figure 6). Several $3 \mathrm{~m}$ wide rows with $46 \mathrm{~cm}$ row spacing of snap beans were planted along a $11.2 \mathrm{~m}$ long by $2.4 \mathrm{~m}$ wide strip in the center, upslope section of the field. Switchgrass buffer strips, alternating with strips of bare soil $1.8 \mathrm{~m}$ long by $2.8 \mathrm{~m}$ wide, were planted downslope from the edge of the bean field. For WS, the switchgrass was planted by direct seeding on the buffer strip areas. For DS, the switchgrass was grown in trays for 4-5 weeks and transplanted as sod. Soil was raked to provide a smooth slope from the snap bean area to the buffer area. A sprinkler irrigation system was set up and used twice a week (if no rain occurred) to provide $1.3 \mathrm{~cm}$ of water per irrigation. Figure 7 shows a picture of the test plot with the switchgrass buffer strip and strip of bare soil. Beans received $72 \mathrm{~kg} \mathrm{ha}^{-1} 10-10-10$ solid fertilizer broadcasted after emergence. Switchgrass received monthly applications of approximately $10 \mathrm{~kg} \mathrm{ha}^{-1}$ liquid 10-10-10 as a foliar spray. 


\section{Establishment of Switchgrass}

Establishment of switchgrass for the buffer strips was very difficult. In WS, the switchgrass was seeded onto the switchgrass buffer areas. Most of the switchgrass was overtaken by weeds before the seeds had a chance to germinate. Several species of weeds composed of 60 to 70 percent of the buffer strips, with the remainder being switchgrass. The most commonly found weeds in the buffer strip are listed in Figure 8. Efforts were made to maintain the plots weed-free by hand-weeding and re-seeding, but these were unsuccessful.

Establishment of switchgrass in DS, was attempted by growing the switchgrass in trays, like sod, and then transplanting them to the location of the buffer strips. Although more switchgrass cover was achieved this way, the switchgrass could not fully compete with the weeds. About 20-30 percent of the switchgrass buffer strip was covered with weeds during DS. Furthermore, all the switchgrass that was transplanted as sod died by the time the experiment was completed.

Endosulfan Application

Once plants reached the 2-3 leaf growth stage endosulfan was applied at a rate of $1.12 \mathrm{~kg}$ a.i. ha ${ }^{-1}$ with a backpack sprayer and hand wand as a foliar spray (Figure 9). The commercial brand Thionex ${ }^{\circledR} 50 \mathrm{~W}$ (wettable powder, $50 \%$ a.i.), manufactured by Makhteshim Agan of North America, Inc., was used. Figure 10 indicates the dates of endosulfan application for WS and DS.

\section{Soil Sampling}

Soil in the switchgrass buffer strip and bare soil areas was sampled the day before endosulfan application and 1, 7, 14,28, and 49 days after the day of application. Samples 
were taken at $0.3,0.9$, and $1.5 \mathrm{~m}$ from the edge of the bean field in both the switchgrass buffer strip and bare soil areas. Soil samples, extracted with a $2 \mathrm{~cm}$ diameter sampler to a depth of $18 \mathrm{~cm}$, were divided between depths of 0-6 $\mathrm{cm}$ (upper layer), 6-12 cm (middle layer), and $12-18 \mathrm{~cm}$ (lower layer) from the soil surface. At each sampling date a different row was randomly selected and sampled in the switchgrass buffer strip and in the bare soil areas. Figure 10 indicates the days the soil was sampled for WS and DS. Soil samples were stored in labeled sampling bags at $4{ }^{\circ} \mathrm{C}$ for no longer than two weeks before analysis.

Endosulfan Analysis

Endosulfan was extracted from soil samples using the method described in Siddique et al. (2003). Three grams each of air dried soil sample was shaken with $10 \mathrm{~mL}$ of acetonitrile for 1 hour at $180 \mathrm{rpm}$ on a New Brunswick Scientific Innova 2100 platform shaker. Solid particles were allowed to settle and the slurry was centrifuged with at $3400 \mathrm{rpm}$ for 10 minutes on a Fisher Scientific Marathon $8 \mathrm{~K}$ bench-model centrifuge. The supernatant was decanted, and the resulting mixture was stored in glass vials in the dark at $4{ }^{\circ} \mathrm{C}$ for $5-6$ weeks until analysis. Endosulfan was analyzed using reversed phase high performance liquid chromatography (RP-HPLC) for $\alpha$-endosulfan, $\beta$-endosulfan, and endosulfan sulfate. The mobile phase was acetonitrile:water $(70: 30 \mathrm{v} / \mathrm{v})$ at a flow rate of $1 \mathrm{~mL} \mathrm{~min}^{-1}$. The injection volume was $20 \mu \mathrm{L}$. Standards for $\alpha$-endosulfan, $\beta$ endosulfan, and endosulfan sulfate were purchased from Chem Service, Inc. Retention times were as follows: 8 min for endosulfan sulfate; 10.2 min for $\beta$-endosulfan; and 11.4 $\min$ for $\alpha$-endosulfan. 
Soil microbial analysis was conducted for all soil samples collected at 0.3 and 0.9 $\mathrm{m}$ from the edge of bean field. Only the top layer $(0-6 \mathrm{~cm}$ from surface) was analyzed. Analyses were conducted in triplicate. Soil moisture content was determined before analysis with a small part $(10 \mathrm{~g})$ of the soil samples.

For soil fungi analysis, $1 \mathrm{~g}$ of each soil sample was diluted with normal saline solution $(0.9 \% \mathrm{w} / \mathrm{v}$ of $\mathrm{NaCl})$ by $10^{-3}, 10^{-4}$ and $10^{-5} \mathrm{~mL}$ and spread on dichloran-rose bengal (DRBA) agar for analysis of fungi. To make 25 plates of DRBA, $15.8 \mathrm{~g}$ of dichloran-rose bengal chloramphenicol agar from Becton, Dickinson and Company (BD) were stirred into $500 \mathrm{~mL}$ of deionized $\mathrm{H}_{2} \mathrm{O}$ in a $1 \mathrm{~L}$ glass container and loosely capped. Agar was then autoclaved at $121^{\circ}$ for 15 min (liquids cycle) in a Harvey SterileMax steam sterilizer. Under aseptic conditions, $20 \mathrm{~mL}$ of the liquid agar was poured onto each media plate and allowed to congeal for one hour. Plates were closed airtight and stored upside-down at room temperature for one week. One $\mu \mathrm{L}$ each of the diluted soil samples was then spread under aseptic conditions onto each media plate with a plastic spreader. Plates were closed with self-sealing film and stored upside-down in the dark at room temperature for analysis. Fungal enumeration was carried out at 24, 48, 72, 96, 120, 144, 168 , and $336 \mathrm{~h}$. Recorded fungal counts were calculated with the equation

$$
F_{r}=F_{o}\left(\frac{W_{d}}{W_{w}}\right)
$$

where $F_{o}$ is the observed fungal counts on a media plate, $W_{d}$ is the dry soil weight, $W_{w}$ is the wet soil weight, and $F_{r}$ are the recorded fungal counts used for analysis. 
For soil bacteria analysis, $1 \mathrm{~g}$ of each soil sample was diluted with normal saline solution $(0.9 \% \mathrm{w} / \mathrm{v}$ of $\mathrm{NaCl})$ by $10^{-5}, 10^{-6}$ and $10^{-7} \mathrm{~mL}$ and spread on tryptic soy agar (TSA) with cycloheximide for analysis of bacterial colonies. To make 25 plates of TSA, $1.5 \mathrm{~g}$ of BD Bacto tryptic soy broth and $7.5 \mathrm{~g}$ of BD Bacto agar were stirred with $500 \mathrm{~mL}$ of deionized $\mathrm{H}_{2} \mathrm{O}$ and loosely capped. Agar was autoclaved at $121^{\circ}$ for 15 min. (liquids cycle). In a $10 \mathrm{~mL}$ beaker, $100 \mathrm{mg}$ of Sigma cycloheximide was stirred with $7 \mathrm{~mL}$ of deionized $\mathrm{H}_{2} \mathrm{O}$ until dissolved. Cycloheximide solution was filtered aseptically with a $200 \mathrm{~nm}$ filter into the agar container and stirred until evenly mixed. Under aseptic conditions, $20 \mathrm{~mL}$ of the liquid agar was poured onto each media plate and allowed to congeal for one hour. Plates were closed airtight and stored upside-down at room temperature for one week. One $\mu \mathrm{L}$ each of the diluted soil samples was then spread under aseptic conditions onto each media plate with a plastic spreader. Plates were closed with self-sealing film and stored upside-down in the dark at $28^{\circ} \mathrm{C}$ for analysis. Bacterial enumeration was carried out at $24,48,72,96,120,144,168$, and $336 \mathrm{~h}$. Recorded bacterial counts were calculated with the equation

$$
B_{r}=B_{0}\left(\frac{W_{d}}{W_{w}}\right)
$$

where $B_{0}$ is the observed fungal counts on a media plate, $W_{d}$ is the dry soil weight, $W_{w}$ is the wet soil weight, and $\mathrm{B}_{\mathrm{r}}$ are the recorded fungal counts used for analysis.

\section{$\underline{\text { Statistical Analysis }}$}

Statistically significant differences between fungal or bacterial populations in the bare soil areas and switchgrass filter strips during the tested days, distances, and seasons were determined post-experiment by an analysis of variance (ANOVA). The statistical 
package SPSS (version 15) was used to calculate the one-way, two-way, and multivariate ANOVAs for all possible interactions between cover, season, day, and distance. Data were checked for normality prior to the ANOVA. Non-normal data were transformed using the mathematical transformation square root $(\sqrt{ } \mathrm{x}+.05)$ for fungi and bacteria and rechecked for normality. Holm's sequential Bonferroni procedure was used for the threeway comparisons. Statistically significant differences between treatments were determined at alpha $(\alpha)=0.05$. 


\section{CHAPTER IV}

\section{RESULTS}

\section{Endosulfan Analysis}

RP-HPLC analysis of the soil samples did not yield the characteristic signals for $\alpha, \beta$, and endosulfan sulfate. Endosulfan concentrations in the runoff from the bean field, if any, must have been below the RP-HPLC detection limit of $0.3 \mathrm{ppm}$. The solutions of the extracted endosulfan from the soil samples have been saved and will be analyzed post-experiment by gas chromatography with electron capture detector (ECD-GC), which can detect endosulfan concentrations as low as $0.002 \mathrm{ppm}$. Samples analyzed by ECDGC will examined for $\alpha$-endosulfan, $\beta$-endosulfan, and endosulfan sulfate.

Research performed by Joseph et al. (2007) on the same field plot as this research was conducted indicates that there were no statistically significant differences observed on soil respiration during the wet and dry seasons before and after endosulfan application. During the wet season, $\mathrm{CO}_{2}$ levels averaged at $335.8 \mu \mathrm{mol} \mathrm{mol}^{-1}$, soil moisture at 8.15 mbar, and soil temperature at $28.0^{\circ} \mathrm{C}$. During the dry season, $\mathrm{CO}_{2}$ levels were 281.1 $\mu \mathrm{mol} \mathrm{mol}{ }^{-1}$, soil moisture $7.7 \mathrm{mbar}$, and soil temperature $21.9^{\circ} \mathrm{C}$. The $\mathrm{pH}$ of all soil samples was $7.8 \pm 0.2$.

\section{Soil Fungi}

As explained in the Methods section, soil samples were diluted to $10^{-3}, 10^{-4}$ and $10^{-5} \mathrm{~mL}$ before fungi analysis. Samples diluted to $10^{-3} \mathrm{~mL}$ had the most normal population distribution. The soil in dilutions $10^{-4}$ and $10^{-5} \mathrm{~mL}$ was too diluted for fungal enumeration. Fungal counts for dilution $10^{-3} \mathrm{~mL}$ were mathematically transformed by using their square root for further analysis of soil fungi. For discussion purposes, the 
results presented here take into consideration this mathematical transformation and the dilution factor.

The ANOVA revealed a significant individual effect by season, cover, and day. The treatment interactions between season and cover; season and day; cover and day; season, distance and day; cover, distance and day; and season, cover, distance and day were also found to have a significant effect on soil fungi $(\mathrm{p}<0.05)$ (Table 1$)$. Season comparison:

Overall mean fungal counts were significantly higher during DS than during WS $(\mathrm{p}<0.0001)$ (Table 2; Figure 11). During WS fungal counts had a mean of 3.504 and a $95 \%$ confidence interval of 2.764 and 4.243 . During DS fungal counts had a mean of 8.787 and a $95 \%$ confidence interval of 8.047 and 9.526 .

Cover comparison:

Overall mean fungal counts were also significantly higher in the switchgrass buffer strip than in the bare soil areas $(\mathrm{p}<0.0001)$ (Table 3; Figure 11). Fungal counts had a mean of 7.606 with a $95 \%$ confidence interval of 6.867 and 8.346 for the switchgrass buffer strip and a mean of 4.684 with a $95 \%$ confidence interval of 3.944 and 5.423 for the bare soil areas.

Day comparison:

Overall mean fungal counts also significantly increased through time $(\mathrm{p}<$ 0.0001 ). The fungal count mean for both seasons was 4.805 for day $0,5.781$ for day 1 and 7.850 for day 28 , though variation exits (Table 4; Figure 12). 
Treatment interactions:

Total soil fungi during WS was not significantly different between the bare soil and switchgrass buffer strip treatments $(p=0.080)$ (Table 5). Soil fungi had a mean of 2.847 and a $95 \%$ confidence interval of 1.801 and 3.893 for the bare soil treatment. For the switchgrass buffer strip, the mean soil fungi count was 4.161 with a $95 \%$ confidence interval of 3.115 and 5.207 (Table 6). There was more variability in the switchgrass buffer strip treatment at $0.9 \mathrm{~m}$ than for any other treatment or distance in WS (Figure 13).

Total soil fungi was statistically different between treatments for DS $(p<0.0001)$ (Table 5). Soil fungi had a mean of 6.521 for the bare soil treatment and a $95 \%$ confidence interval of 5.475 and 7.567 . For the switchgrass buffer strip, soil fungi averaged at 11.052 and had a $95 \%$ confidence interval of 10.006 and 12.098 (Table 6). There was more variability within treatments and distances for DS than for WS (Figure 14).

In the bare soil area at $0.3 \mathrm{~m}$, fungal counts decreased by about $50 \%$ from day 0 $($ mean $=3.804)$ to day $1($ mean $=1.831)$, but this difference was not found to be statistically significant $(p=0.128)$. The increase from day 1 to day $28($ mean $=8.786)$ at $0.3 \mathrm{~m}$ was by about $500 \%$ and was found to be statistically significant at the $\alpha=0.05$ level (Table 7, 8; Figure 12). At $0.9 \mathrm{~m}$, the same trend was observed, with a small decline in fungal counts between day $0($ mean $=3.901)$ and day $1($ mean $=2.789)$ that is not statistically significant $(p=0.387)$, followed by a significant increase in fungal counts ( $p$ $=0.002)$ between day 1 and $28($ mean $=6.993)($ Table 7,$8 ;$ Figure 12).

Fungal counts in the switchgrass buffer strip followed a different trend. At $0.3 \mathrm{~m}$ there was a significant increase in fungal counts $(p=0.006)$ between day 0 (mean $=$ 
$5.632)$ and day $1($ mean $=9.290)$, then a significant decrease $(p=0.002)$ between day 1 and day $28($ mean $=5.091)$. Fungal counts at day 0 and day 28 were not different $(p=$ 0.673 ) (Table 7, 8; Figure 12). At $0.9 \mathrm{~m}$ fungal counts increased significantly $(\mathrm{p}=0.012)$ between day $0($ mean $=5.882)$ and day $1($ mean $=9.216)$, followed by a small increase between day 1 and day $28($ mean $=10.528)$ that was not significant $(p=0.308)($ Table 7 , 8 ; Figure 12).

\section{Soil Bacteria}

Soil samples were diluted to $10^{-5}, 10^{-6}$ and $10^{-7} \mathrm{~mL}$ before bacterial analysis. Samples diluted to $10^{-6} \mathrm{~mL}$ had the most normal population distribution. The soil in dilution $10^{-5}$ showed too many bacterial colonies for analysis and the soil in dilution $10^{-7}$ $\mathrm{mL}$ was too diluted to provide enough bacterial colonies for analysis. Bacterial counts for dilution $10^{-6} \mathrm{~mL}$ were mathematically transformed by using their square root for further analysis of soil bacteria. For discussion purposes, the results presented here take into consideration this mathematical transformation and the dilution factor.

The soil bacteria ANOVA revealed a significant individual effect by season and day. The treatment interactions between cover and distance; season and day; distance and day; season, cover and distance; and season, distance and day were also found to have a significant effect on soil fungi $(\mathrm{p}<0.05)$ (Table 9).

Season comparison:

Overall mean bacterial counts were significantly higher in WS than in DS ( $p<$ 0.0001) (Table 10; Figure 15). During WS bacterial counts had a mean of 192.151 and a $95 \%$ confidence interval of 181.257 and 203.044. During DS bacterial counts had a mean of 8.552 and a $95 \%$ confidence interval of -2.341 and 19.445 (Table 10 ). 
Cover comparison:

Overall mean bacterial counts were higher in the switchgrass buffer strip than in the bare soil areas, but this difference was not significant at the $\alpha=0.05$ level $(p=0.221)$ (Table 11, Figure 15). Bacterial counts had a mean of 105.100 with a $95 \%$ confidence interval of 94.206 and 115.993 for the switchgrass buffer strip and a mean of 95.603 with a $95 \%$ confidence interval of 84.710 and 106.496 for the bare soil areas (Table 11). Day comparison:

Overall mean bacterial counts significantly increased through time $(p<0.0001)$. The bacterial count mean for both seasons was 25.993 for day $0,125.258$ for day 1 , and 149.802 for day 28 (Table 12; Figure 16).

Treatment interactions:

Total soil bacteria during WS was not significantly different between the bare soil and switchgrass buffer strip treatments $(\mathrm{p}=0.159)$ (Table 13). Soil bacterial counts had a mean of 184.408 , with a $95 \%$ confidence interval of 169.003 and 199.814 for the bare soil treatment. For the switchgrass buffer strip, soil bacterial counts averaged at 199.893 with a $95 \%$ confidence interval of 184.487 and 215.298 (Table 14; Figure 15).

Soil bacterial counts were not significantly different between bare soil and switchgrass buffer strip treatments in DS $(p=0.747)$ (Table 13), although bacteria in the switchgrass was slightly higher. The mean soil bacterial counts was 6.797 with a $95 \%$ confidence interval of $-8,608$ and 22.202 for the bare soil treatment. For the switchgrass buffer strip, soil bacteria averaged at 10.306 and had a $95 \%$ confidence interval of -5.099 and 25.712 (Table 14; Figure 15). 
Bacteria increased steadily in the bare soil area from day 0 to day 1 to day 28 at the $0.3 \mathrm{~m}$ distance. On day 0 mean bacterial counts were 52.846 . By day 1 mean bacterial count was 79.783, which was not significantly different at the $\alpha=0.05$ level $(\mathrm{p}=0.158)$. The increase in bacterial counts between day 1 and day 28 was significant $(\mathrm{p}<0.0001)$, averaging at 180.508 (Table 15, 16; Figure 16). At $0.9 \mathrm{~m}$ a different trend was observed: there was a significant increase $(p<0.0001)$ in bacterial counts between day $0($ mean $=$ $4.309)$ and day $1($ mean $=135.685)$. A small decrease in bacteria occurred by day 28 , where the mean was 53.016. This decrease was not significant at the $\alpha=0.05$ level $(\mathrm{p}=$ 0.034) (Table 15, 16; Figure 16).

Bacterial populations in the switchgrass buffer strip followed a similar trend to that found in the bare soil area. At $0.3 \mathrm{~m}$ bacteria significantly increased from day 0 $($ mean $=43.288)$ to day $1($ mean $=84.846)(p=0.032)$. Another significant increase occurred by day $28($ mean $=163.782)(\mathrm{p}<0.0001)($ Table 15, 16; Figure 16). At $0.9 \mathrm{~m}$ bacterial counts also increased significantly between day $0($ mean $=3.528)$ and day 1 $($ mean $=200.720)(p<0.0001)$. However, there was a significant decline in bacterial counts by day $28($ mean $=134.433)(p=0.001)($ Table 15, 16; Figure 16). 


\section{DISCUSSION \& CONCLUSIONS}

\section{Use of Switchgrass Buffer Strips in South Florida}

Switchgrass is native to South Florida and a suggested species for buffer strips by the USDA (USDA, 1999). However, this experiment showed the complexities of switchgrass as the main vegetation in a buffer strip to reduce pesticide runoff due to the problems in establishment and maintenance. Other studies have had success in reducing contaminants using a switchgrass buffer strip (Blanco-Canqui et al., 2005; Mersie et al., 2005). The literature also indicates that Panicum virgatum is a hardy grass that tolerates drought, very wet conditions, poor soils, and can be weedy or invasive in certain circumstances (USDA, 2001). However, the unexpected hardships in establishing switchgrass faced during this study indicate otherwise. The poor establishment of the grass and high maintenance required to prevent weeds from overtaking the switchgrass buffer strip and keeping it alive makes it inefficient for use in buffer strips in practical scenarios.

The difficulty in establishing the switchgrass might have been due to the tillage practice to the buffer strip area prior to switchgrass establishment. The seeds of weeds that were there prior to the experiment could have germinated when exposed to sunlight and taken over before the switchgrass seeds were able to germinate. Whether this is true or not, farmers and landowners do not want to spend their resources in establishing buffer strips that create complexities. Installation of buffer strips often does not benefit the landowners themselves, but the surrounding land, water, and environment. Herbaceous plants used for buffer strips should be easy to establish, very low maintenance, and 
overall inexpensive to retain. They should also perform the task required, namely preventing sediment, pesticide, and nutrient runoff.

An assessment of the location of the buffer strip should be done prior to establishing a grass for this purpose. Local grasses that effectively reduce runoff and remain in the designated area throughout the year should be used first. Although there was natural switchgrass adjacent to the test plot for part of the year, the grass "moved" as the weather changed and was eventually replaced by other grasses and broadleaf plants. The switchgrass near the test field seemed to prefer shaded areas, where weed competition is at a minimum. Farmers and landowners know their property best and have seen the succession throughout the years and weather events. They should work closely with experts to determine which grasses are best for them to use in buffer strips. Effects of Endosulfan Runoff on Soil Fungi and Bacteria

Research performed by Joseph et al. (2007) on the same field plot as this research was conducted indicates that there were no statistically significant differences observed on soil respiration rates before and after endosulfan application. Soil respiration normally refers to the total outflow of $\mathrm{CO}_{2}$ at the soil surface. It is the combination of biotic, chemical and physical processes. This is an indication that microbial respiration, a biotic process, was not affected by the application of endosulfan.

The RP-HPLC endosulfan analysis did not provide any positive results because of the lower detection limit of $0.3 \mathrm{ppm}$, therefore, the specific effects of endosulfan on soil fungi and bacteria cannot be determined. ECD-GC analysis of endosulfan concentrations in the soil is required to accurately measure lower concentrations of endosulfan in the soil 
not detected by the RP-HPLC. The ECD-GC can detect endosulfan concentrations as low as $0.002 \mathrm{ppm}$ to determine the effects of endosulfan on soil fungi and bacteria.

It can be assumed that the runoff from the bean field did not contain amounts of endosulfan high enough to be deadly to most insects and higher animals at the $1.12 \mathrm{~kg}$ a.i. $\mathrm{ha}^{-1}$ application rate per the toxicity estimates provided in the EPA's ECOTOXicology database (EPA, 2007). Endosulfan concentrations causing mortality to bird species (LD $\mathrm{D}_{50}$ ) are above $690 \mathrm{ppm}$ except for the Northern bobwhite (Colinus virginianus) and the Mallard duck (Anas platyrhynchos), whose $\mathrm{LD}_{50}$ are 42 and 28 ppm respectively (EPA, 2007). The $\mathrm{LD}_{50}$ of most insects, except for a few that are targeted by endosulfan, are also well above the $0.3 \mathrm{ppm}$ detection limit of the RP-HPLC. No reptiles have an $\mathrm{LD}_{50}$ of $0.3 \mathrm{ppm}$ or less (EPA, 2007). However, an $\mathrm{LD}_{50}$ of $0.3 \mathrm{ppm}$ or below is common in amphibians, some worms, crustaceans, and fish (Kegley, 2007). Endosulfan concentrations below $0.3 \mathrm{ppm}$ might not cause death in most species; however, they can affect important neurological processes in several species causing imbalance, confusion, difficulty breathing, convulsions, temporary blindness, loss of consciousness, and even deformations.

It is important to note that endosulfan is toxic to humans, animals, and insects. The results of our studies are not meant to replace or contradict the warnings and suggestions made by the EPA and other toxicity studies, or provided on the endosulfan pesticide label. This study imitated two yearly applications of endosulfan on a small field. The accumulation of endosulfan runoff could and probably would be greater along steeper sloping farmland, in larger fields, in farmland that is adjacent other farmland 
using endosulfan, and in land that has had endosulfan application for extended periods of time.

\section{Effects of Switchgrass Buffer Strip on Soil Fungi and Bacteria}

Switchgrass had a positive effect on soil fungi and bacteria. The mean fungal counts for all seasons, distances, and days for the bare soil areas was 4.684. For the switchgrass buffer strip, it was 7.606 (Table 3 ). The mean bacterial count for the bare soil areas was 95.603. For the switchgrass buffer strip, it was 105.100 (Table 11).

According to the Soil Biology Primer (Tugel et al., 2000) and other sources (Alexander, 1977; Wood, 1989; Bardgett, 2005) bacteria are more competitive when substrates that are easy to metabolize are present. This includes fresh, young plant residue and the compounds found near living roots. Bacteria are especially concentrated in the rhizosphere, where plants produce certain types of root exudates to encourage the growth of protective bacteria. Fungal growth is also promoted with plant residue. The switchgrass in the buffer strip and the exudates from its extensive root system encouraged growth of bacteria and fungi. The bare soil areas lacked this factor and therefore supported less bacteria and fungi.

The results from this study indicate that buffer strips increase soil bacteria and fungi and may be able to filter harmful bacteria from agricultural fields before reaching a body of water (Staddon et al., 2001; Boyer, 2006). As previously described, fungi and especially bacteria can metabolize a wide range of chemicals including pesticides (Wood, 1989). Buffer strips can therefore decrease pesticide runoff by preventing the sediment to which pesticide adsorbs and by metabolizing the pesticides that reach it. Since bacteria 
and fungi also cycle nutrients, fertilizer runoff can also be reduced by these soil organisms in the buffer strip.

Seasonal Effects on Soil Fungi and Bacteria

There was a significant difference in soil fungi and bacteria between the wet season and the dry season. Soil fungi more than doubled from the wet season to the dry season. The mean fungal count during the wet season was 3.504 . During the dry season, it was 8.787 (Table 2). Season had an opposite effect for soil bacteria. During the wet season, the mean bacterial count was 115.688. During the dry season, it dropped to 15.777 (Table 10).

These results support the literature stating that, in drier conditions, soil bacteria die or go dormant and soil fungi has an advantage since they can use their hyphae to get to the moisture pockets in the soil (Bardgett, 2005). During the wet season, bacteria dominated in the soil. During the dry season, fungi dominated in the soil and bacterial numbers plummeted. The difference in soil fungi between the wet and dry seasons is not as great as the difference in soil bacteria because fungi also flourish in wet conditions. 


\begin{tabular}{|l|c|c|c|c|}
\hline Common name & technical endosulfan & alpha $(\alpha)$ endosulfan & beta ( $(\mathrm{B})$ endosulfan & endosulfan sulfate \\
\hline Empirical formula & $\mathrm{C}_{9} \mathrm{H}_{6} \mathrm{Cl}_{6} \mathrm{O}_{3} \mathrm{~S}$ & $\mathrm{C}_{9} \mathrm{H}_{6} \mathrm{Cl}_{6} \mathrm{O}_{3} \mathrm{~S}$ & $\mathrm{C}_{9} \mathrm{H}_{6} \mathrm{Cl}_{6} \mathrm{O}_{3} \mathrm{~S}$ & $\mathrm{C}_{9} \mathrm{H}_{6} \mathrm{Cl}_{6} \mathrm{SO}_{4}$ \\
\hline Molecular structure & & & &
\end{tabular}

at $25^{\circ} \mathrm{C}$ 
Figure 2: Metabolism of endosulfan. From Ballschmitter et al., 1967.

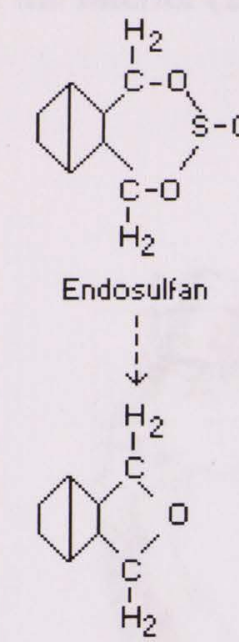

Endosulfan ether
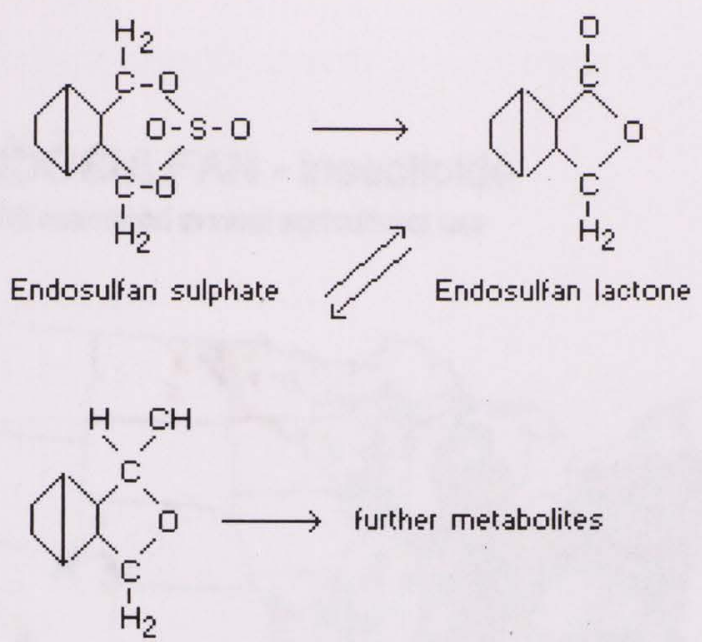

Endosulfan hydronyether<smiles>OCC1C2CCC(C2)C1CO</smiles>

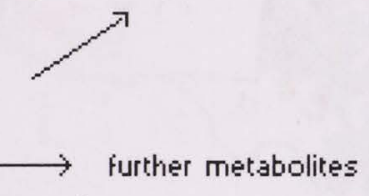

Endosulfan diol

Figure 3: Target pests of endosulfan, adapted from EPA (2002).

\section{Target Pests:}

Meadow spittlebug, Army cutworm, Aphids, Bean leaf skeletonizer, Cowpea curculio, Cucumber beetle, Flea beetle, Green stink bug, Leafhoppers, Mexican bean beetles, Cabbage looper, Cabbage worm, Cabbage aphid, Cucumber beetles, Whitefly, Cutworms, Thrips, Diamondback moth, Corn earworm, Boll weevil, Bollworm, Lygus bugs, Melonworm, Pickleworm, Rindworm, Squash beetle, Squash bug, Blister beetle, Potato beetle, Rose chafer, Pepper maggot, Cinch bug, Crown mite, June bug, Harlequin bug, Grape phylloxera, and Grape leafhopper. 
Figure 4: Agricultural use of endosulfan in the United States in 2002 created by the US Dept. of the Interior (2002).

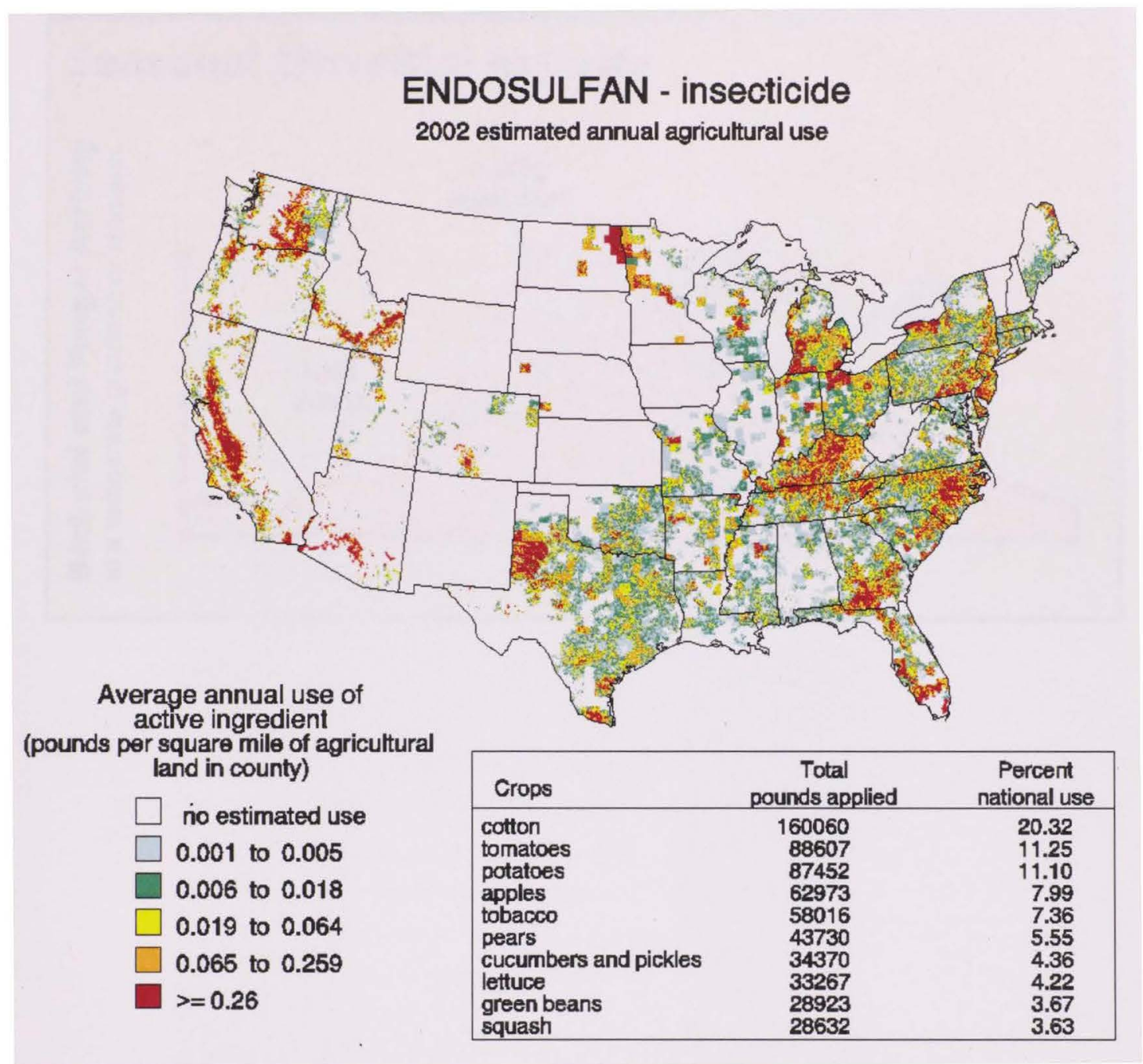


Figure 5: Seasonal microbial activity in a temperate grassland or cropland, created by Tugel et al.(2000).

\section{Seasonal Microbial Activity}
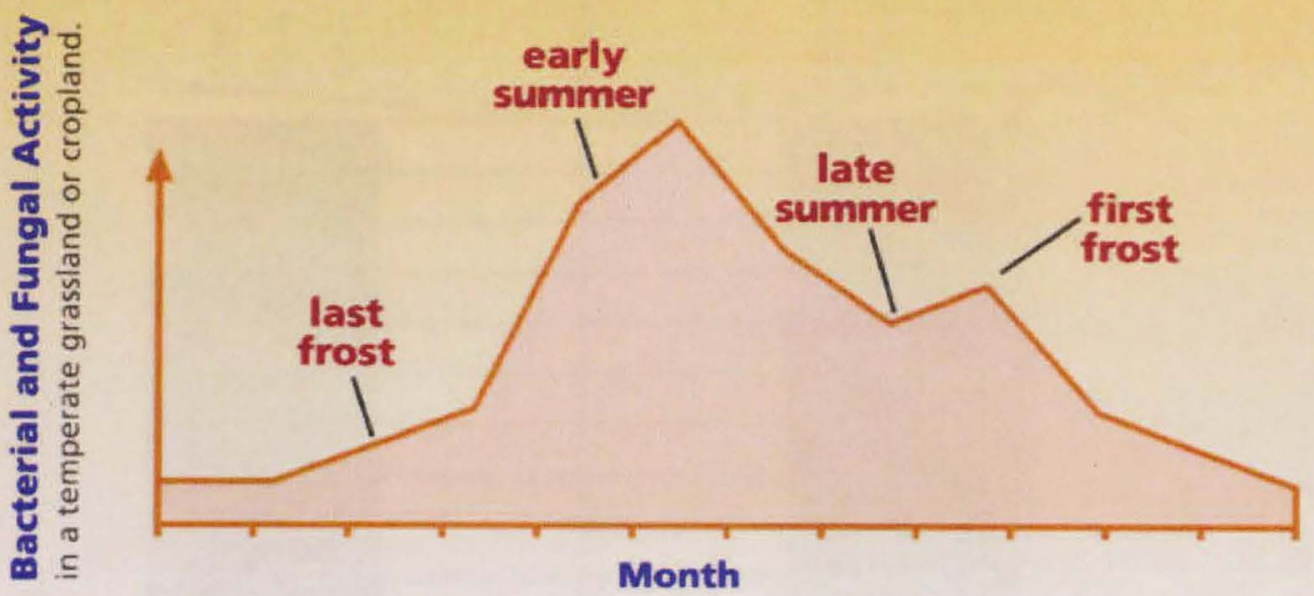


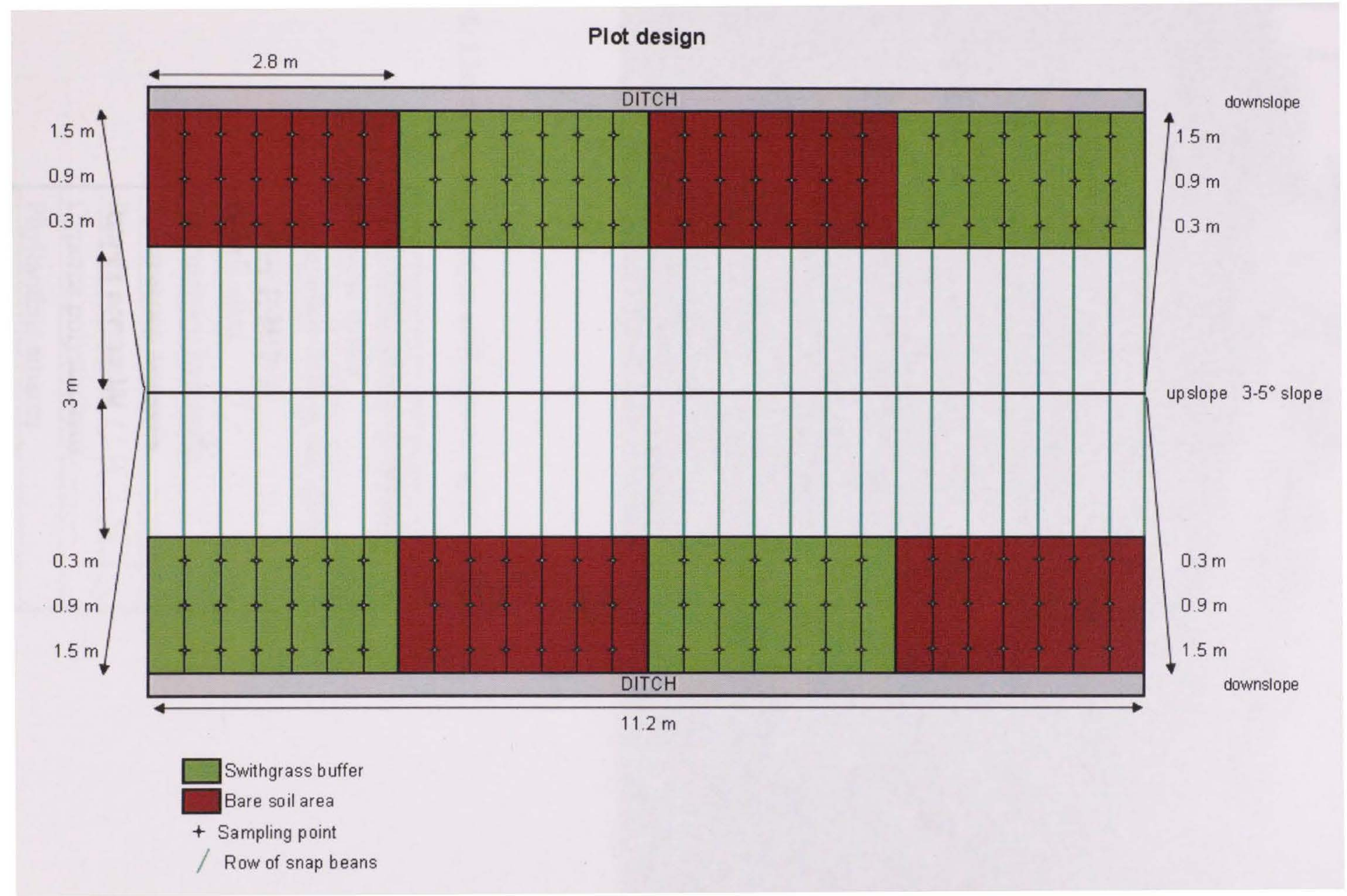

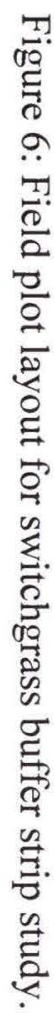


Figure 7: Test plot with the switchgrass buffer strip (left) and strip of bare soil (right).

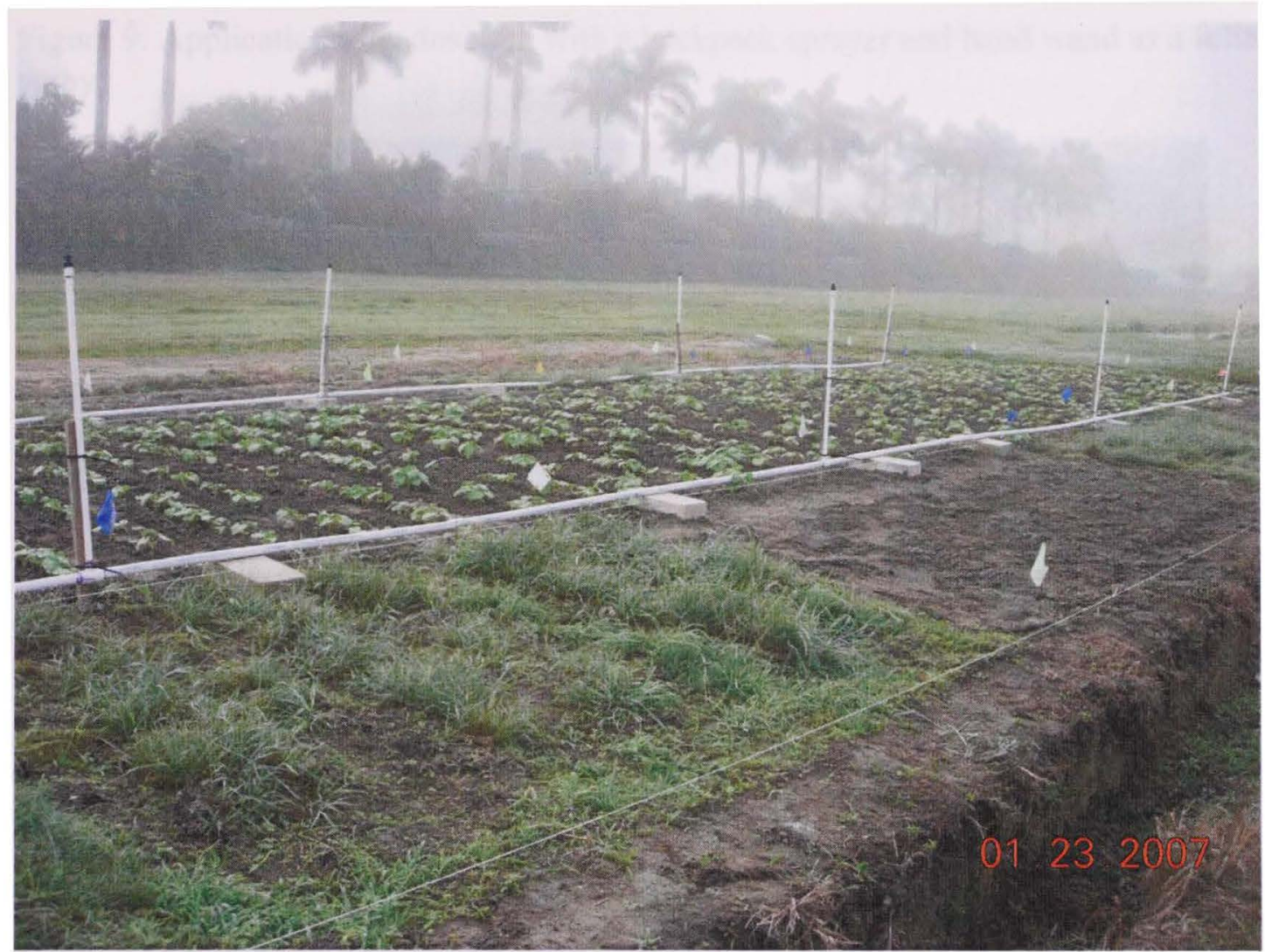

Figure 8: List of weeds found in switchgrass buffer strips.

\begin{tabular}{|l|}
\hline Scientific name of weeds: \\
\hline Eleusine indica \\
\hline Commelina diffusa var. diffusa \\
\hline Seteria parviflora \\
\hline Hyptis alata \\
\hline Spermacoce terminalis \\
\hline Spermacoce asurgens \\
\hline Rumex acetosella \\
\hline Cyperus polystachyos \\
\hline Phyllanthus amarus \\
\hline Bidens alba \\
\hline Cyperus surinamensis \\
\hline
\end{tabular}


Figure 9: Application of endosulfan with a backpack sprayer and hand wand as a foliar spray.
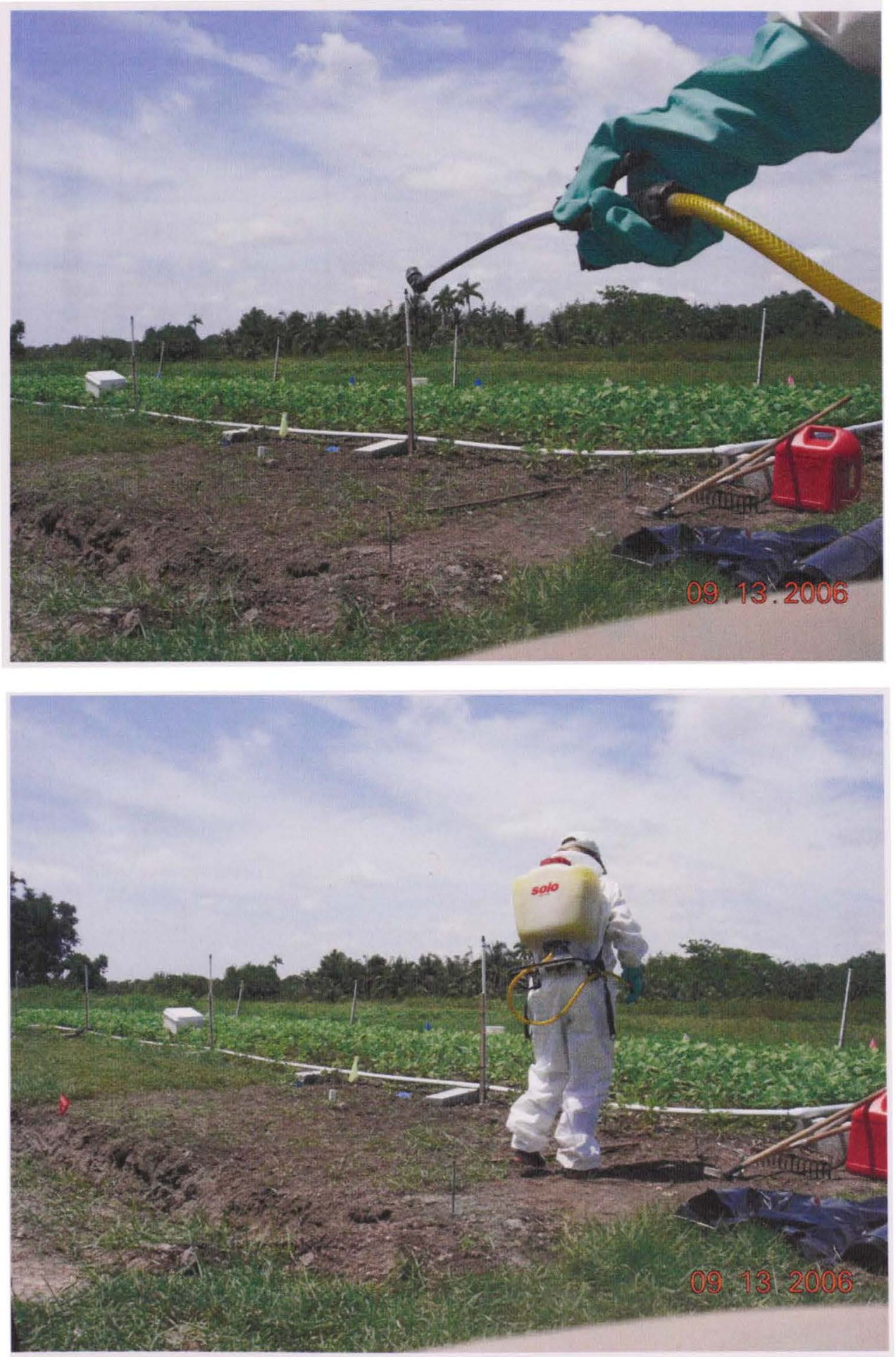
Figure 10: Important dates of experiment.

\begin{tabular}{|c|c|c|c|}
\hline \multicolumn{2}{|c|}{ Season } & $\begin{array}{l}\text { Wet } \\
\text { (Summer to Fall 2006) }\end{array}$ & $\begin{array}{l}\text { Dry } \\
\text { (Winter to Spring 2007) }\end{array}$ \\
\hline \multicolumn{2}{|c|}{ Planting of switchgrass } & June 7 th, 2006 & November 15th, 2006 \\
\hline \multicolumn{2}{|c|}{ Planting of beans } & August 17th, 2006 & December 20th, 2006 \\
\hline \multicolumn{2}{|c|}{ Endosulfan application } & September 13th, 2006 & January 25th, 2007 \\
\hline \multirow{6}{*}{ 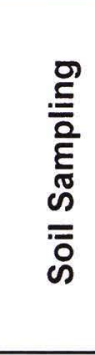 } & Day 0 & September 13th, 2006 & January 25 th, 2007 \\
\hline & Day 1 & September 14th, 2006 & January 26th, 2007 \\
\hline & Day 7 & September 20th, 2006 & February 1st, 2007 \\
\hline & Day 14 & September 27th, 2006 & February 8th, 2007 \\
\hline & Day 28 & October 11th, 2006 & February 22nd, 2007 \\
\hline & Day 49 & November 11th, 2006 & March 14th, 2007 \\
\hline \multicolumn{2}{|c|}{ Removal of bean plants } & October 18th 2006 & March 13th. 2007 \\
\hline
\end{tabular}


Figure 11: Comparison of fungal count for bare soil and switchgrass treatments for wet and dry seasons.

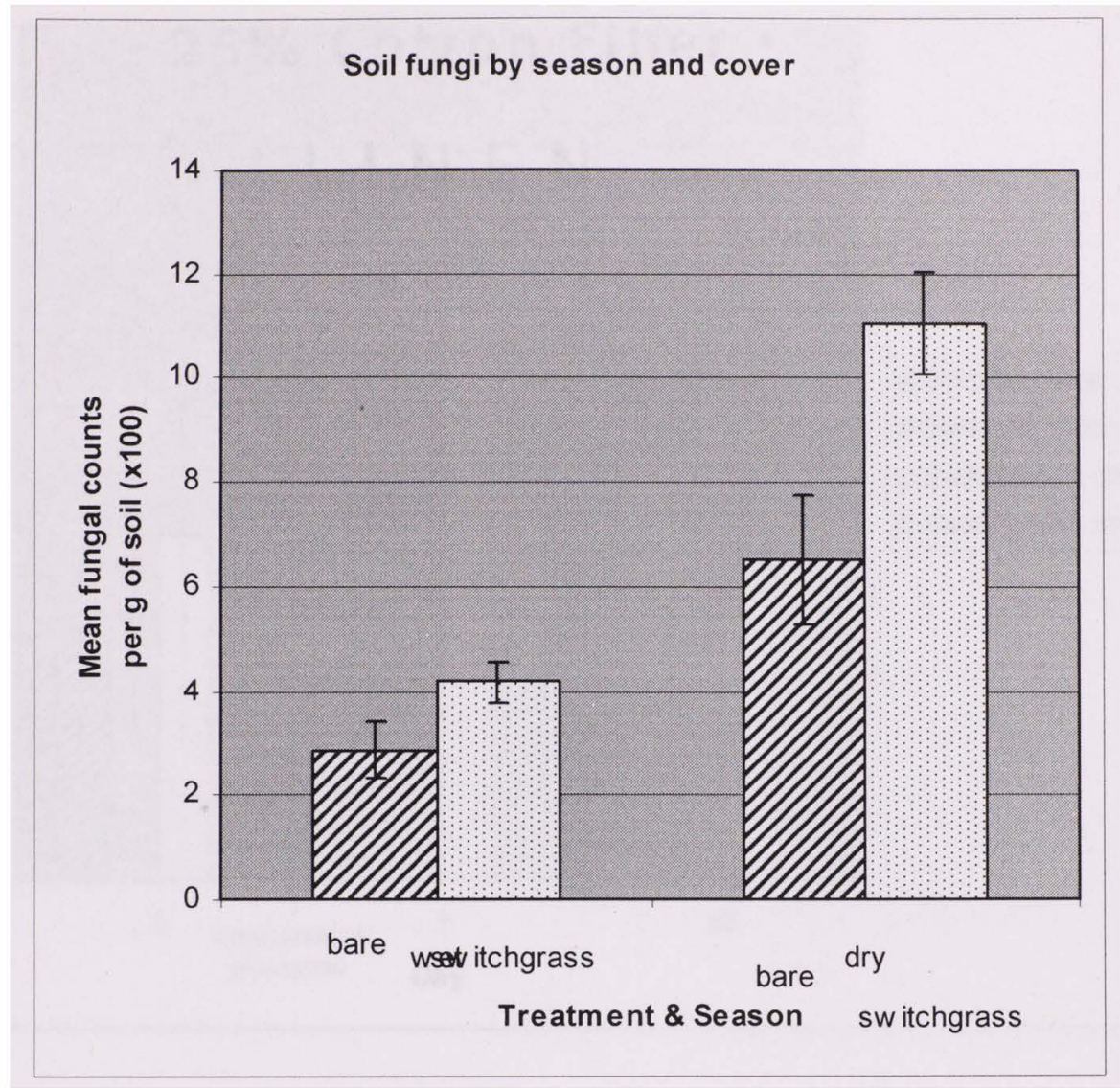


Figure 12: Fungal count by day, distance, and plant cover.

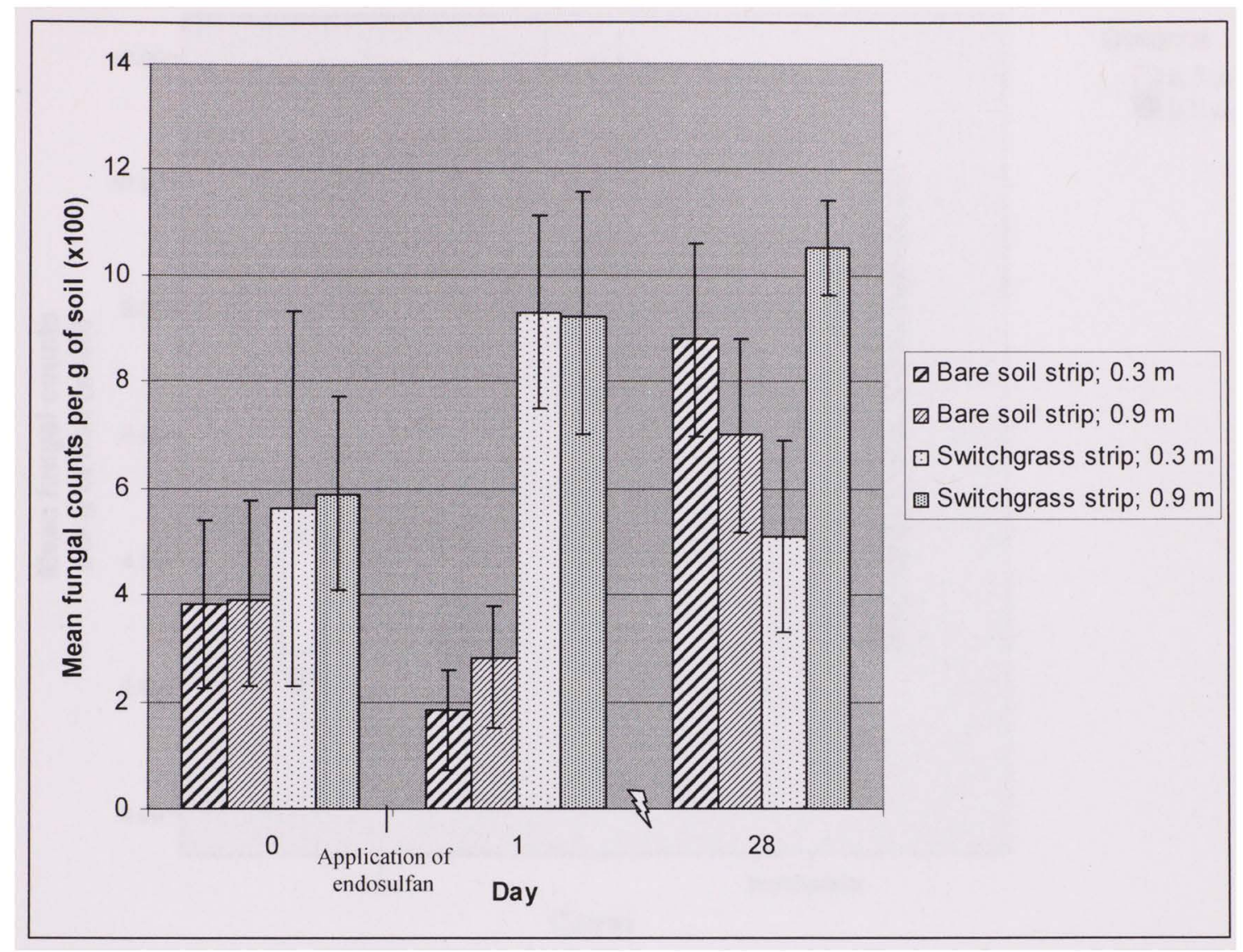


Figure 13: Box plot of fungal count for wet season.

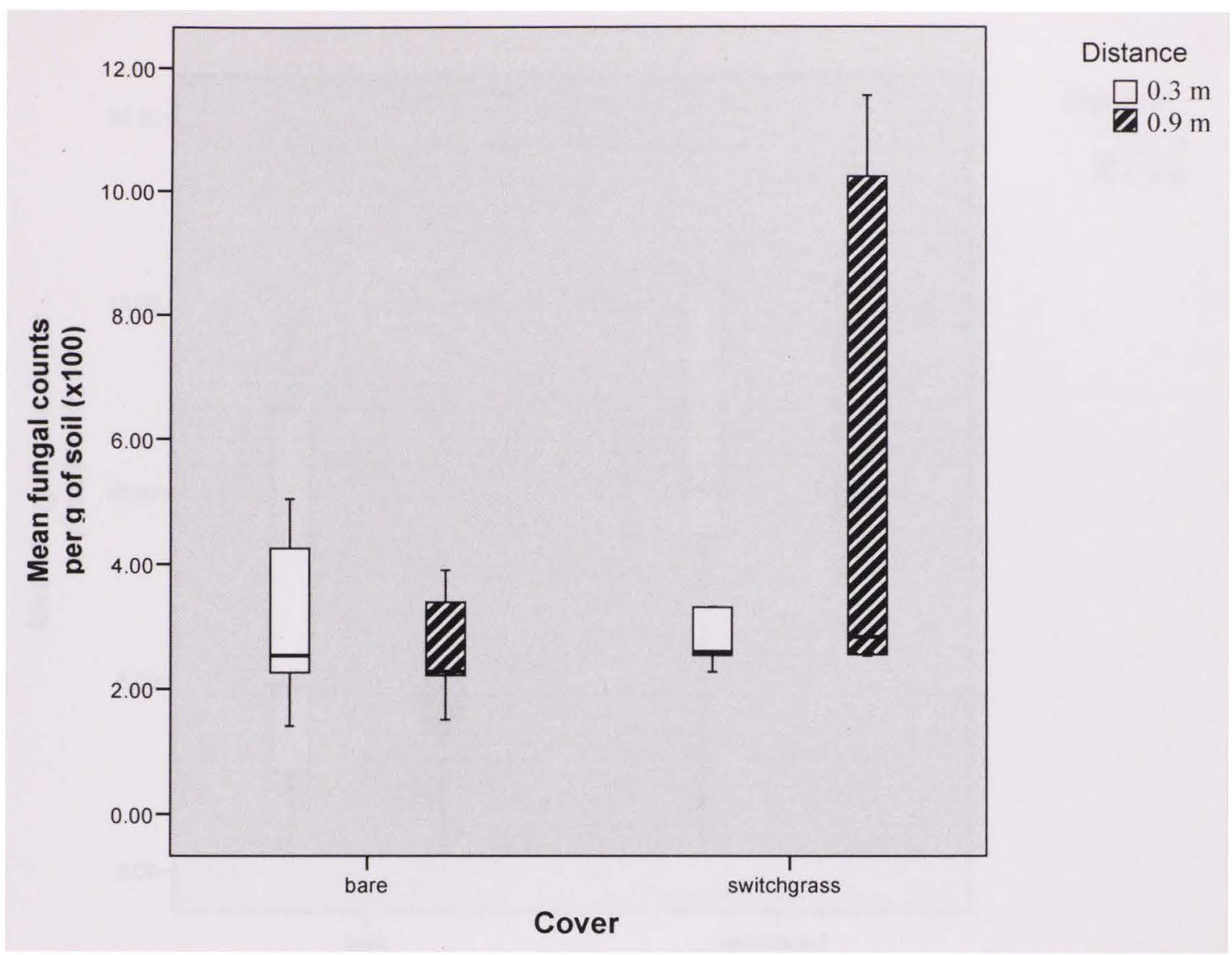


Figure 14: Box plot of fungal count for dry season.

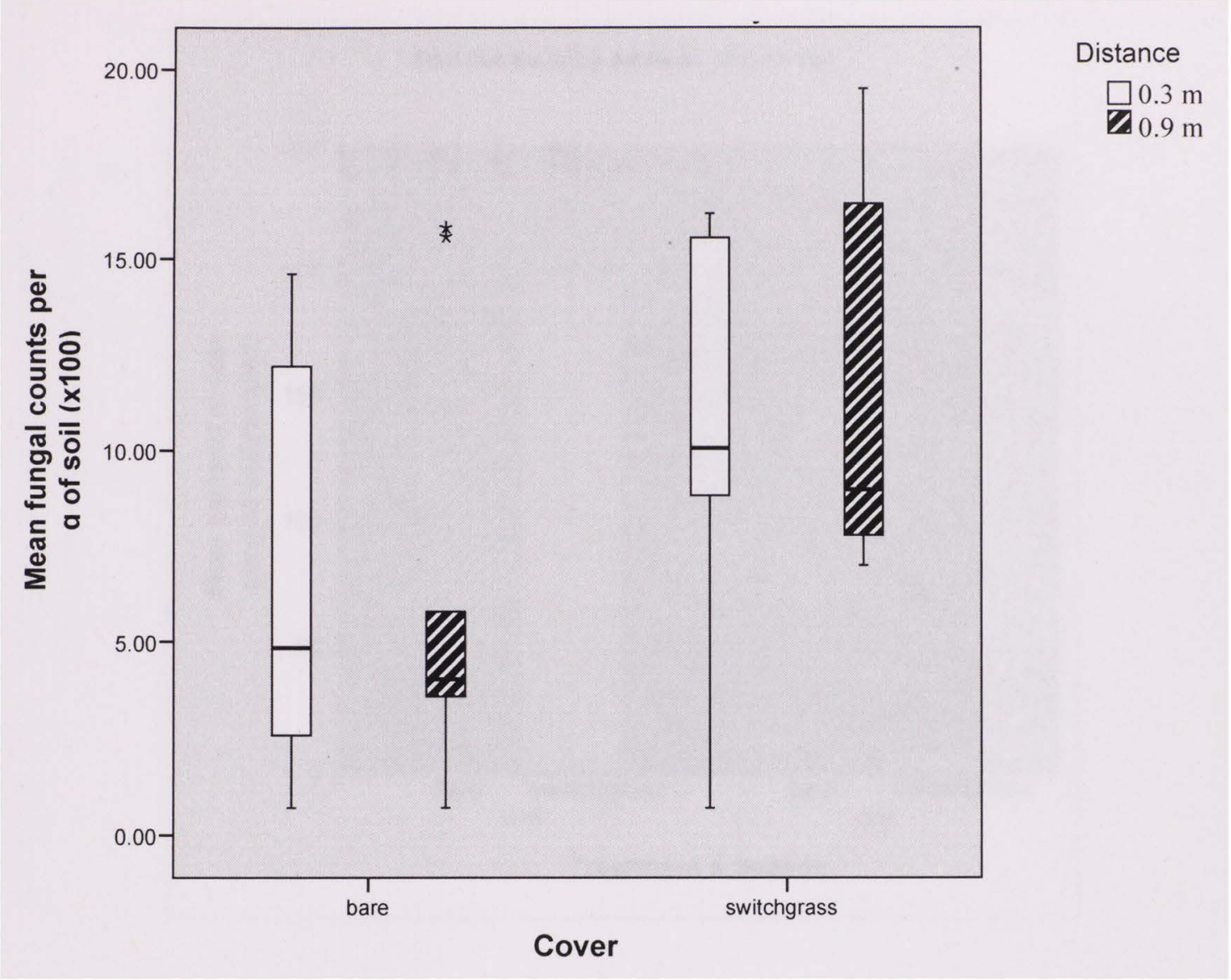


Figure 15: Comparison of bacterial count for bare soil and switchgrass treatments for wet and dry seasons.

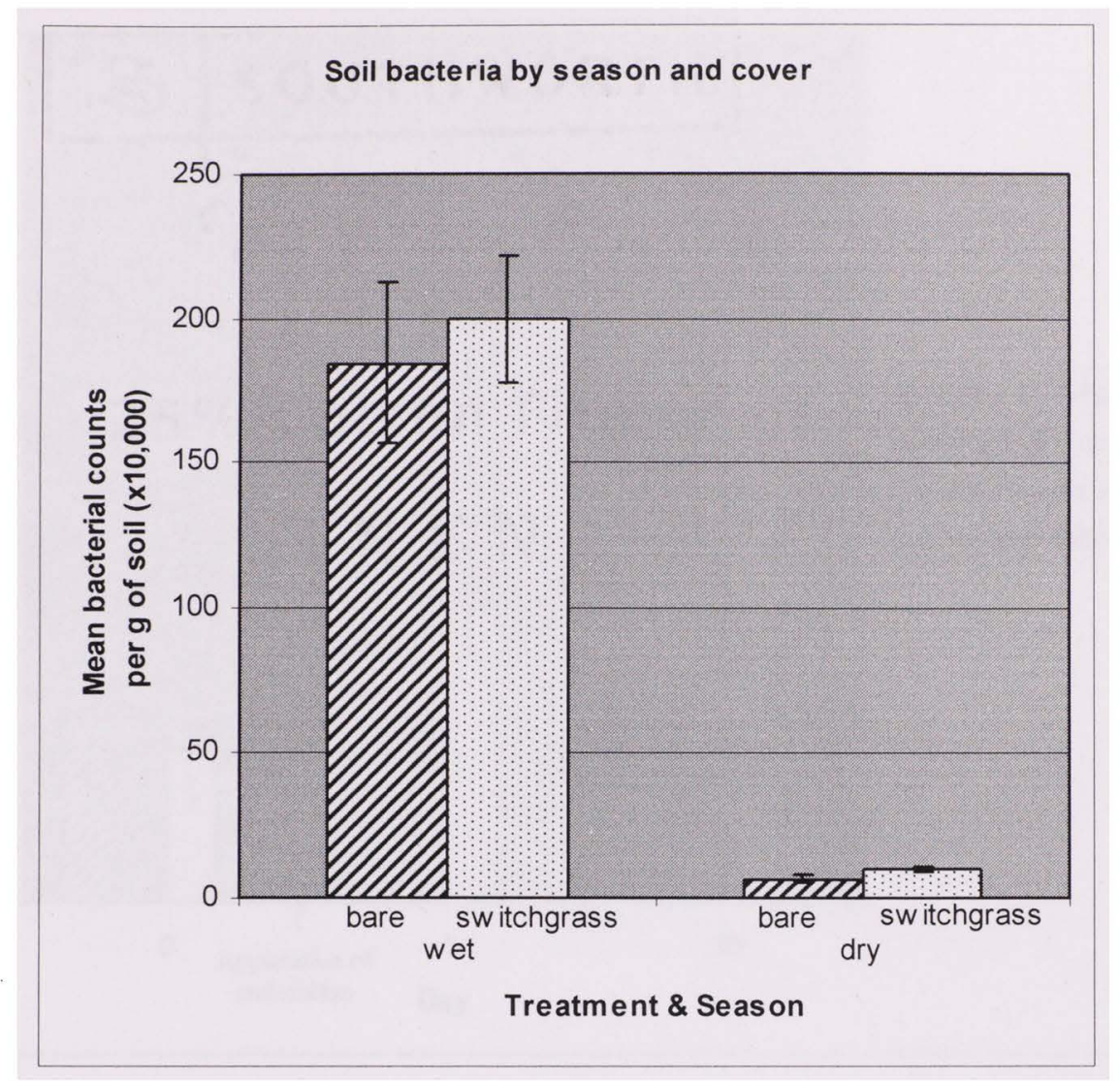


Figure 16: Bacterial count by day, distance, and plant cover.

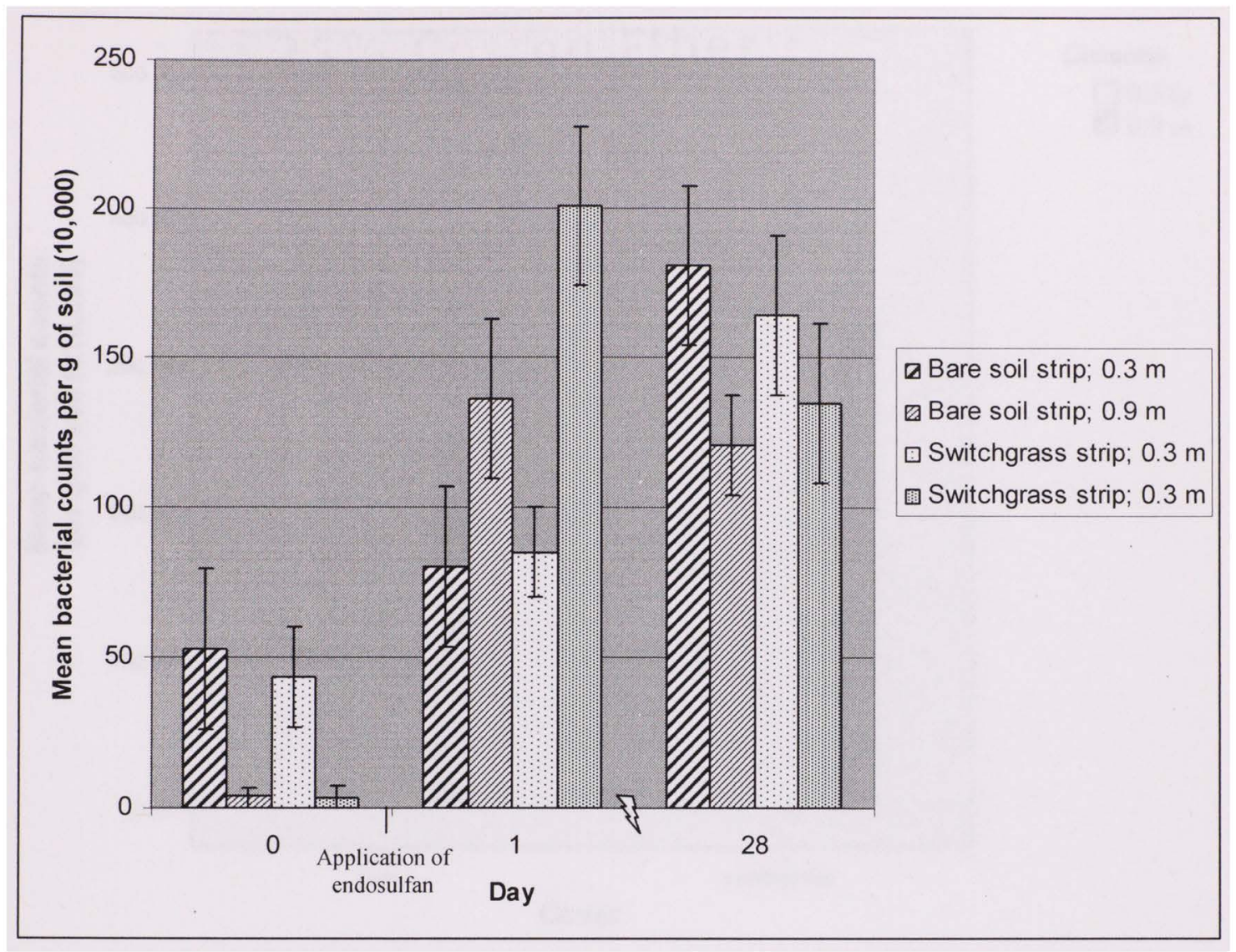


Figure 17: Box plot of bacterial count for wet season.

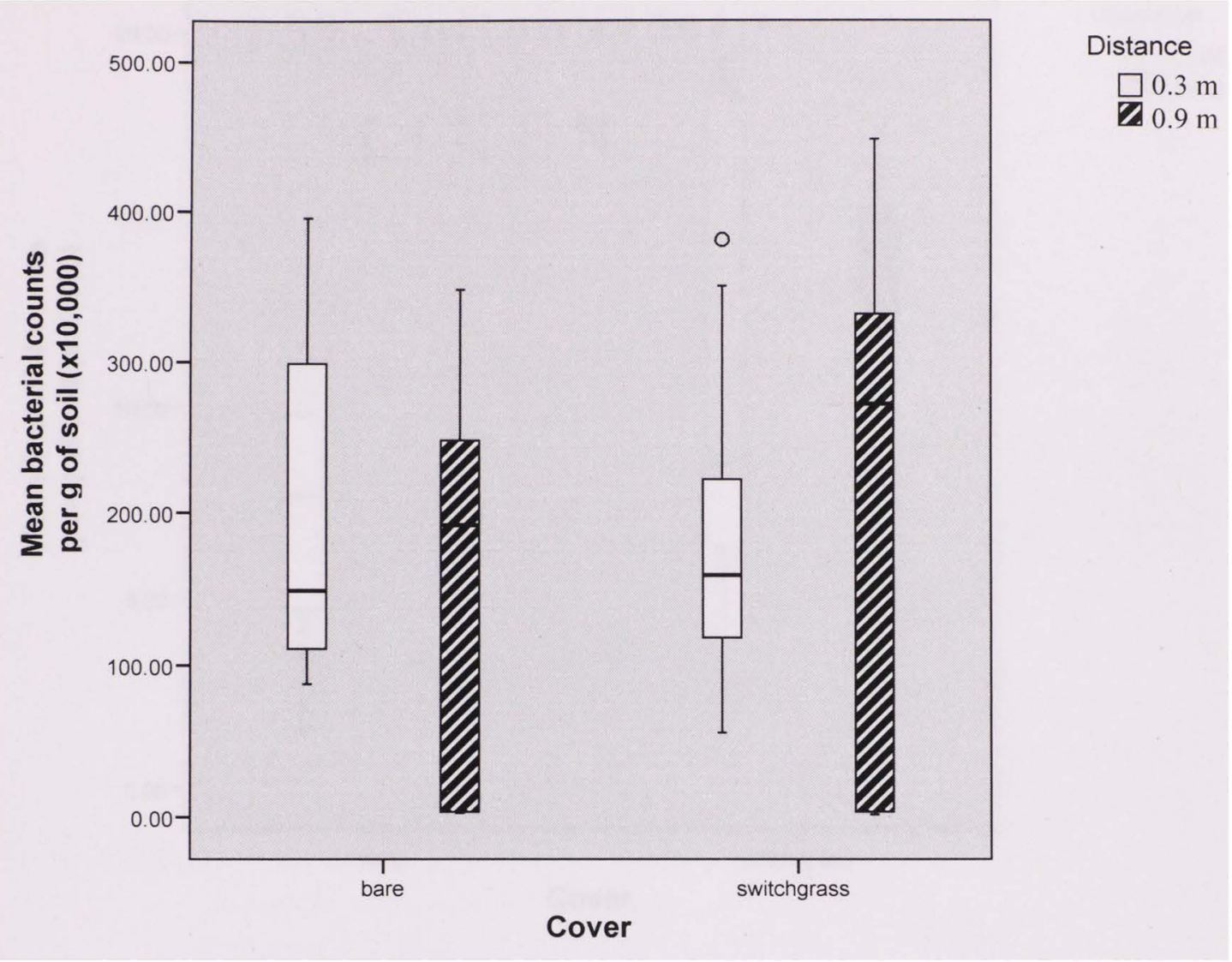


Figure 18: Box plot of bacterial count for dry season.

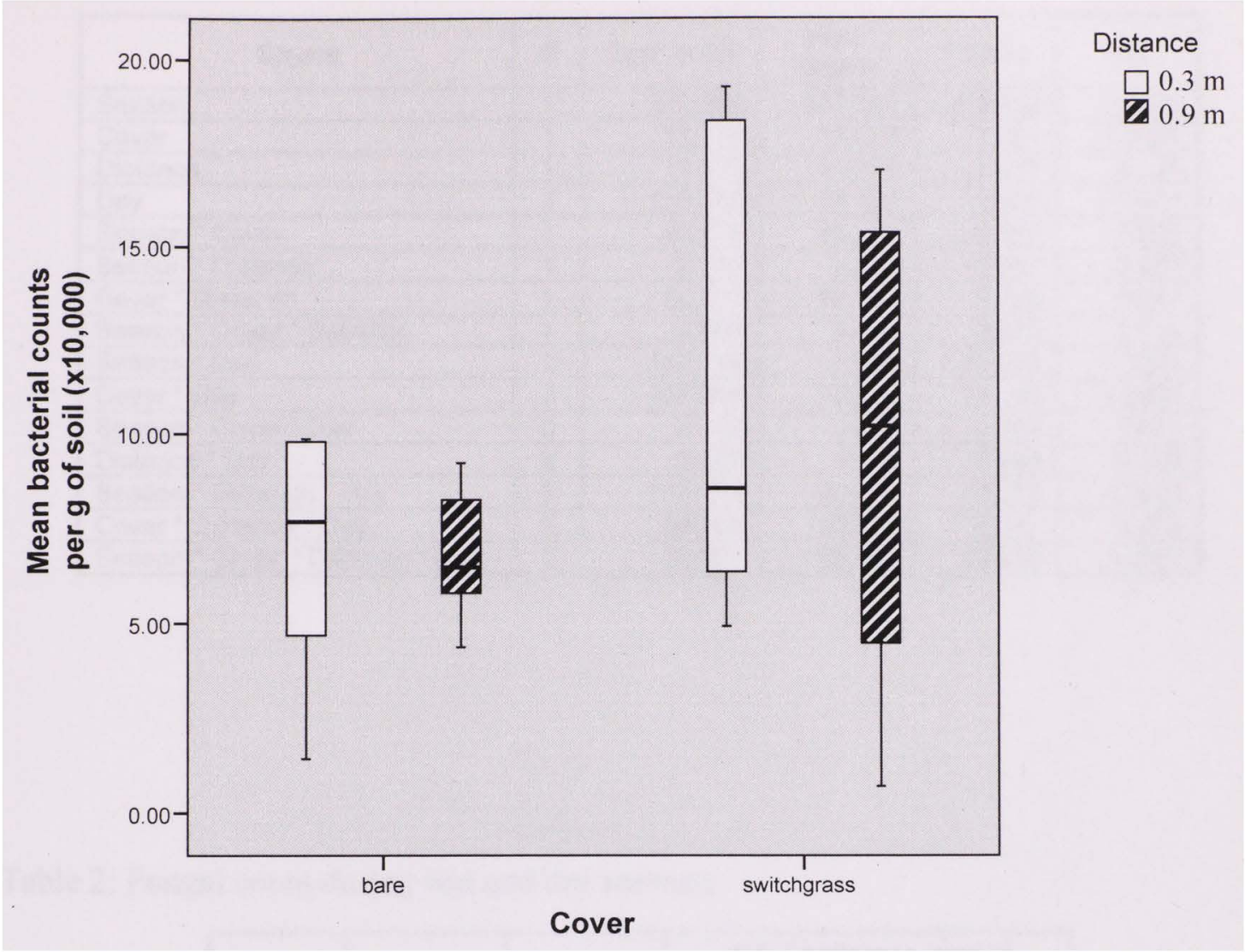


Table 1: Fungal count ANOVA table.

\begin{tabular}{|l|r|r|r|r|r|}
\hline \multicolumn{1}{|c|}{ Source } & df & \multicolumn{1}{c|}{ Type III SS } & \multicolumn{1}{c|}{$\begin{array}{c}\text { Mean } \\
\text { Square }\end{array}$} & \multicolumn{1}{c|}{ F Value } & \multicolumn{1}{c|}{ Sig. } \\
\hline Season & 1 & 502.384 & 502.384 & 103.132 & $<.0001$ \\
\hline Cover & 1 & 153.74 & 153.74 & 31.561 & $<.0001$ \\
\hline Distance & 1 & 11.879 & 11.879 & 2.439 & 0.125 \\
\hline Day & 2 & 116.018 & 58.009 & 11.908 & $<.0001$ \\
\hline Season * Cover & 1 & 46.578 & 46.578 & 9.562 & 0.003 \\
\hline Season * Distance & 1 & 2.735 & 2.735 & 0.562 & 0.457 \\
\hline Cover * Distance & 1 & 20.163 & 20.163 & 4.139 & 0.047 \\
\hline Season * Cover * Distance & 1 & 4.504 & 4.504 & 0.925 & 0.341 \\
\hline Season * Day & 2 & 117.719 & 58.86 & 12.083 & $<.0001$ \\
\hline Cover * Day & 2 & 157.308 & 78.654 & 16.146 & $<.0001$ \\
\hline Season * Cover * Day & 2 & 6.512 & 3.256 & 0.668 & 0.517 \\
\hline Distance *Day & 2 & 9.383 & 4.691 & 0.963 & 0.389 \\
\hline Season *Distance * Day & 2 & 119.574 & 59.787 & 12.273 & $<.0001$ \\
\hline Cover * Distance * Day & 2 & 59.886 & 29.943 & 6.147 & 0.004 \\
\hline Season * Cover * Distance * Day & 2 & 176.901 & 88.451 & 18.158 & $<.0001$ \\
\hline
\end{tabular}

Table 2: Fungal count during wet and dry seasons.

\begin{tabular}{|c|r|r|r|r|}
\hline \multirow{2}{*}{ Season } & \multirow{2}{*}{ Mean } & \multirow{2}{*}{ Std Error } & \multicolumn{2}{|c|}{$95 \%$ Confidence Interval } \\
\cline { 4 - 5 } & & & Lower Bound & Upper Bound \\
\hline wet & 3.504 & .368 & 2.764 & 4.243 \\
\hline dry & 8.787 & .368 & 8.047 & 9.526 \\
\hline
\end{tabular}

Table 3: Fungal count for bare soil and switchgrass buffer strip treatments.

\begin{tabular}{|c|r|r|r|r|}
\hline \multirow{2}{*}{ Cover } & \multirow{2}{*}{ Mean } & \multirow{2}{*}{ Std. Error } & \multicolumn{2}{|c|}{$95 \%$ Confidence Interval } \\
\cline { 3 - 5 } & & & Lower Bound & Upper Bound \\
\hline bare & 4.684 & .368 & 3.944 & 5.423 \\
\hline switchgrass & 7.606 & .368 & 6.867 & 8.346 \\
\hline
\end{tabular}


Table 4: Fungal count for days 0,1 , and 28.

\begin{tabular}{|c|r|r|r|r|}
\hline \multirow{2}{*}{ Day } & \multirow{2}{*}{ Mean } & \multirow{2}{*}{ Std. Error } & \multicolumn{2}{|c|}{$95 \%$ Confidence Interval } \\
\cline { 4 - 5 } & & & Lower Bound & Upper Bound \\
\hline 0 & 4.805 & .451 & 3.899 & 5.711 \\
\hline 1 & 5.781 & .451 & 4.875 & 6.687 \\
\hline 28 & 7.850 & .451 & 6.944 & 8.755 \\
\hline
\end{tabular}

Table 5: Pairwise comparisons between seasons and plant covers for fungal count.

\begin{tabular}{|c|l|l|r|r|r|}
\hline Season & (I) Cover & (J) Cover & $\begin{array}{c}\text { Mean } \\
\text { Difference } \\
(1-J)\end{array}$ & $\begin{array}{c}\text { Std. } \\
\text { Error }\end{array}$ & Sig.(a) \\
\hline wet & bare & switchgrass & -1.314 & .736 & .080 \\
\hline & switchgrass & bare & 1.314 & .736 & .080 \\
\hline dry & bare & switchgrass & $-4.531\left(^{\star}\right)$ & .736 & .000 \\
\hline & switchgrass & bare & $4.531\left(^{\star}\right)$ & .736 & .000 \\
\hline
\end{tabular}

Based on estimated marginal means

* The mean difference is significant at the 05 level.

a Adjustment for multiple comparisons: Least Significant Difference (equivalent to no adjustments).

Table 6: Fungal count by season and plant cover.

\begin{tabular}{|c|l|r|r|r|r|}
\hline \multirow{2}{*}{ Season } & \multirow{2}{*}{ Cover } & \multirow{2}{*}{ Mean } & \multirow{2}{*}{$\begin{array}{c}\text { Std. } \\
\text { Error }\end{array}$} & & \multicolumn{2}{|c|}{$95 \%$ Confidence Interval } \\
\cline { 5 - 6 } & & 2.847 & .520 & Lower Bound & Upper Bound \\
\hline wet & bare & 4.161 & .520 & 1.801 & 3.893 \\
\hline & switchgrass & 6.521 & .520 & 3.115 & 5.207 \\
\hline dry & bare & 11.052 & .520 & 10.006 & 7.567 \\
\hline & switchgrass & 12.098 \\
\hline
\end{tabular}


Table 7: Fungal count for bare soil and switchgrass buffer strip treatments, distance, and days 0,1 , and 28 .

\begin{tabular}{|c|c|c|c|c|c|c|}
\hline \multirow{2}{*}{ Cover } & \multirow{2}{*}{ Distance } & \multirow{2}{*}{ Day } & \multirow{2}{*}{ Mean } & \multirow{2}{*}{ Std. Error } & \multicolumn{2}{|c|}{$95 \%$ Confidence Interval } \\
\hline & & & & & Lower Bound & Upper Bound \\
\hline \multirow[t]{6}{*}{ bare } & \multirow[t]{3}{*}{$0.3 \mathrm{~m}$} & 0 & 3.804 & .901 & 1.992 & 5.616 \\
\hline & & 1 & 1.831 & .901 & .019 & 3.642 \\
\hline & & 28 & 8.786 & .901 & 6.975 & 10.598 \\
\hline & \multirow[t]{3}{*}{$0.9 \mathrm{~m}$} & 0 & 3.901 & .901 & 2.090 & 5.713 \\
\hline & & 1 & 2.789 & .901 & .977 & 4.600 \\
\hline & & 28 & 6.993 & .901 & 5.181 & 8.804 \\
\hline \multirow[t]{6}{*}{ switchgrass } & \multirow[t]{3}{*}{$0.3 \mathrm{~m}$} & 0 & 5.632 & .901 & 3.820 & 7.443 \\
\hline & & 1 & 9.290 & .901 & 7.478 & 11.102 \\
\hline & & 28 & 5.091 & .901 & 3.280 & 6.903 \\
\hline & \multirow[t]{3}{*}{$0.9 \mathrm{~m}$} & 0 & 5.882 & .901 & 4.070 & 7.694 \\
\hline & & 1 & 9.216 & .901 & 7.404 & 11.027 \\
\hline & & 28 & 10.528 & .901 & 8.716 & 12.340 \\
\hline
\end{tabular}


Table 8: Pairwise comparisons between treatments and distance for days 0,1 , and 28 for fungal counts.

\begin{tabular}{|c|c|c|c|c|c|c|}
\hline Cover & Distance & (1) Day & (J) Day & $\begin{array}{c}\text { Mean } \\
\text { Difference } \\
(1-J)\end{array}$ & Std. Error & Sig.(a) \\
\hline \multirow{12}{*}{ bare } & \multirow[t]{6}{*}{$0.3 \mathrm{~m}$} & \multirow[t]{2}{*}{0} & 1 & 1.973 & 1.274 & 128 \\
\hline & & & 28 & $-4.982\left(^{*}\right)$ & 1.274 & .000 \\
\hline & & \multirow[t]{2}{*}{1} & 0 & -1.973 & 1.274 & .128 \\
\hline & & & 28 & $-6.956\left(^{*}\right)$ & 1.274 & .000 \\
\hline & & \multirow[t]{2}{*}{28} & 0 & $4.982\left(^{\star}\right)$ & 1.274 & .000 \\
\hline & & & 1 & $6.956\left(^{*}\right)$ & 1.274 & .000 \\
\hline & \multirow[t]{6}{*}{$0.9 \mathrm{~m}$} & \multirow[t]{2}{*}{0} & 1 & 1.113 & 1.274 & 387 \\
\hline & & & 28 & $-3.091\left(^{\star}\right)$ & 1.274 & .019 \\
\hline & & \multirow[t]{2}{*}{1} & 0 & -1.113 & 1.274 & .387 \\
\hline & & & 28 & $-4.204\left(^{*}\right)$ & 1.274 & .002 \\
\hline & & \multirow[t]{2}{*}{28} & 0 & $\left.3.0911^{*}\right)$ & 1.274 & .019 \\
\hline & & & 1 & $4.204\left(^{*}\right)$ & 1.274 & .002 \\
\hline \multirow[t]{12}{*}{ switchgrass } & \multirow[t]{6}{*}{$0.3 \mathrm{~m}$} & \multirow[t]{2}{*}{0} & 1 & $-3.658\left(^{*}\right)$ & 1.274 & .006 \\
\hline & & & 28 & .541 & 1.274 & .673 \\
\hline & & \multirow[t]{2}{*}{1} & 0 & $3.658\left(^{*}\right)$ & 1.274 & .006 \\
\hline & & & 28 & $4.199\left(^{*}\right)$ & 1.274 & .002 \\
\hline & & \multirow[t]{2}{*}{28} & 0 & -.541 & 1.274 & .673 \\
\hline & & & 1 & $\left.-4.1990^{*}\right)$ & 1.274 & .002 \\
\hline & \multirow[t]{6}{*}{$0.9 \mathrm{~m}$} & \multirow[t]{2}{*}{0} & 1 & $-3.334\left(^{*}\right)$ & 1.274 & .012 \\
\hline & & & 28 & $-4.646\left(^{\star}\right)$ & 1.274 & .001 \\
\hline & & \multirow[t]{2}{*}{1} & 0 & $3.334\left(^{\star}\right)$ & 1.274 & .012 \\
\hline & & & 28 & -1.312 & 1.274 & .308 \\
\hline & & \multirow[t]{2}{*}{28} & 0 & $4.646\left(^{*}\right)$ & 1.274 & .001 \\
\hline & & & 1 & 1.312 & 1.274 & .308 \\
\hline
\end{tabular}

Based on estimated marginal means

* The mean difference is significant at the .05 level.

a Adjustment for multiple comparisons: Least Significant Difference (equivalent to no adjustments). 
Table 9: Bacterial count ANOVA table

\begin{tabular}{|l|r|r|r|r|r|}
\hline \multicolumn{1}{|c|}{ Source } & df & Type III SS & \multicolumn{1}{c|}{$\begin{array}{c}\text { Mean } \\
\text { Square }\end{array}$} & F Value & \multicolumn{1}{c|}{ Sig. } \\
\hline Season & 1 & 606753.47 & 606753.47 & 574.205 & $<.0001$ \\
\hline Cover & 1 & 1623.41 & 1623.41 & 1.536 & 0.221 \\
\hline Distance & 1 & 17.369 & 17.369 & 0.016 & 0.899 \\
\hline Day & 2 & 206278.463 & 103139.23 & 97.606 & $<.0001$ \\
\hline Season * Cover & 1 & 645.304 & 645.304 & 0.611 & 0.438 \\
\hline Season * Distance & 1 & 0.049 & 0.049 & 0 & 0.995 \\
\hline Cover * Distance & 1 & 4942.549 & 4942.549 & 4.677 & 0.036 \\
\hline Season * Day & 2 & 190648.851 & 95324.426 & 90.211 & $<.0001$ \\
\hline Cover * Day & 2 & 5919.055 & 2959.528 & 2.801 & 0.071 \\
\hline Distance * Day & 2 & 67918.033 & 33959.016 & 32.137 & $<.0001$ \\
\hline Season * Cover * Day & 2 & 3244.854 & 1622.427 & 1.535 & 0.226 \\
\hline Season * Cover * Distance & 1 & 5456.6 & 5456.6 & 5.164 & 0.028 \\
\hline Season * Distance * Day & 2 & 66126.555 & 33063.278 & 31.29 & $<.0001$ \\
\hline Cover * Distance *Day & 2 & 1979.374 & 989.687 & 0.937 & 0.399 \\
\hline Season * Cover * Distance * Day & 2 & 2351.5 & 1175.75 & 1.113 & 0.337 \\
\hline
\end{tabular}

Table 10: Bacterial count during wet and dry seasons.

\begin{tabular}{|c|r|r|r|r|}
\hline \multirow{2}{*}{ Season } & \multirow{2}{*}{ Mean } & \multirow{2}{*}{ Std. Error } & \multicolumn{2}{|c|}{$95 \%$ Confidence Interval } \\
\cline { 4 - 5 } & & & Lower Bound & Upper Bound \\
\hline wet & 192.151 & 5.418 & 181.257 & 203.044 \\
\hline dry & 8.552 & 5.418 & -2.341 & 19.445 \\
\hline
\end{tabular}

Table 11: Bacterial count for bare soil and switchgrass buffer strip treatments.

\begin{tabular}{|c|r|r|r|r|}
\hline \multirow{2}{*}{ Cover } & \multirow{2}{*}{ Mean } & \multirow{2}{*}{ Std. Error } & \multicolumn{2}{|c|}{$95 \%$ Confidence Interval } \\
\cline { 4 - 5 } & & & Lower Bound & Upper Bound \\
\hline bare & 95.603 & 5.418 & 84.710 & 106.496 \\
\hline switchgrass & 105.100 & 5.418 & 94.206 & 115.993 \\
\hline
\end{tabular}


Table 12: Bacterial count for days 0,1 , and 28.

\begin{tabular}{|c|r|r|r|r|}
\hline \multirow{2}{*}{ Day } & \multirow{2}{*}{ Mean } & \multirow{2}{*}{ Std. Error } & \multicolumn{2}{|c|}{$95 \%$ Confidence Interval } \\
\cline { 4 - 5 } & & & Lower Bound & Upper Bound \\
\hline 0 & 25.993 & 6.635 & 12.651 & 39.334 \\
\hline 1 & 125.258 & 6.635 & 111.917 & 138.600 \\
\hline 28 & 149.802 & 6.635 & 136.461 & 163.144 \\
\hline
\end{tabular}

Table 13: Pairwise comparisons between seasons and plant covers for bacterial counts.

\begin{tabular}{|c|l|l|r|r|r|}
\hline Season & (I) Cover & (J) Cover & $\begin{array}{c}\text { Mean } \\
\text { Difference } \\
(1-J)\end{array}$ & Std. Error & Sig.(a) \\
\hline wet & bare & switchgrass & -15.484 & 10.836 & .159 \\
\hline & switchgrass & bare & 15.484 & 10.836 & .159 \\
\hline dry & bare & switchgrass & -3.509 & 10.836 & .747 \\
\hline & switchgrass & bare & 3.509 & 10.836 & .747 \\
\hline
\end{tabular}

Based on estimated marginal means

* The mean difference is significant at the 05 level.

a Adjustment for multiple comparisons: Least Significant Difference (equivalent to no adjustments).

Table 14: Bacterial count by season and plant cover.

\begin{tabular}{|c|l|r|r|r|r|}
\hline \multirow{2}{*}{ Season } & \multirow{2}{*}{ Cover } & \multirow{2}{*}{ Mean } & \multirow{2}{*}{ Std. Error } & \multicolumn{2}{|c|}{$95 \%$ Confidence Interval } \\
\cline { 5 - 6 } & & & & Lower Bound & Upper Bound \\
\hline wet & bare & 184.408 & 7.662 & 169.003 & 199.814 \\
\hline & switchgrass & 199.893 & 7.662 & 184.487 & 215.298 \\
\hline dry & bare & 6.797 & 7.662 & -8.608 & 22.202 \\
\hline & switchgrass & 10.306 & 7.662 & -5.099 & 25.712 \\
\hline
\end{tabular}


Table 15: Bacterial count for bare soil and switchgrass buffer strip treatments, distance, and days 0,1 , and 28 .

\begin{tabular}{|c|c|c|c|c|c|c|}
\hline \multirow{2}{*}{ Cover } & \multirow{2}{*}{ Distance } & \multirow{2}{*}{ Day } & \multirow{2}{*}{ Mean } & \multirow{2}{*}{ Std. Error } & \multicolumn{2}{|c|}{$95 \%$ Confidence Interval } \\
\hline & & & & & Lower Bound & Upper Bound \\
\hline \multirow[t]{6}{*}{ bare } & \multirow[t]{3}{*}{$0.3 \mathrm{~m}$} & 0 & 52.846 & 13271 & 26.163 & 79.529 \\
\hline & & 1 & 79.783 & 13.271 & 53.101 & 106.466 \\
\hline & & 28 & 180.508 & 13.271 & 153.825 & 207.191 \\
\hline & \multirow{3}{*}{$0.9 \mathrm{~m}$} & 0 & 4.309 & 13.271 & -22.374 & 30.991 \\
\hline & & 1 & 135.685 & 13.271 & 109.002 & 162.367 \\
\hline & & 28 & 120.486 & 13.271 & 93.803 & 147.168 \\
\hline \multirow[t]{6}{*}{ switchgrass } & \multirow[t]{3}{*}{$0.3 \mathrm{~m}$} & 0 & 43.288 & 13.271 & 16.605 & 69.971 \\
\hline & & 1 & 84.846 & 13.271 & 58.163 & 111.529 \\
\hline & & 28 & 163.782 & 13.271 & 137.099 & 190.465 \\
\hline & \multirow[t]{3}{*}{$0.9 \mathrm{~m}$} & 0 & 3.528 & 13.271 & -23.154 & 30.211 \\
\hline & & 1 & 200.720 & 13.271 & 174.037 & 227.402 \\
\hline & & 28 & 134.433 & 13.271 & 107.750 & 161.116 \\
\hline
\end{tabular}


Table 16: Pairwise comparisons between treatments and distance for days 0,1 , and 28 for bacterial count.

\begin{tabular}{|c|c|c|c|c|c|c|}
\hline Cover & Distance & (1) Day & (J) Day & $\begin{array}{c}\text { Mean } \\
\text { Difference } \\
(1-J)\end{array}$ & Std. Error & Sig.(a) \\
\hline \multirow[t]{12}{*}{ bare } & \multirow[t]{6}{*}{$0.3 \mathrm{~m}$} & \multirow[t]{2}{*}{0} & 1 & -26.937 & 18.768 & .158 \\
\hline & & & 28 & $-127.662\left(^{\star}\right)$ & 18.768 & .000 \\
\hline & & \multirow[t]{2}{*}{1} & 0 & 26.937 & 18.768 & 158 \\
\hline & & & 28 & $-100.725(*)$ & 18.768 & .000 \\
\hline & & \multirow[t]{2}{*}{28} & 0 & $127.662\left(^{*}\right)$ & 18.768 & .000 \\
\hline & & & 7 & $100.725\left(^{\star}\right)$ & 18.768 & .000 \\
\hline & \multirow[t]{6}{*}{$0.9 \mathrm{~m}$} & \multirow[t]{2}{*}{0} & $T$ & $\left.-131.3766^{*}\right)$ & 18.768 & .000 \\
\hline & & & 28 & $-116.177\left(^{*}\right)$ & 18.768 & .000 \\
\hline & & \multirow[t]{2}{*}{1} & 0 & $\left.131.3760^{*}\right)$ & 18.768 & .000 \\
\hline & & & 28 & 15.199 & 18.768 & .422 \\
\hline & & \multirow[t]{2}{*}{28} & 0 & $116.177\left(^{*}\right)$ & 18.768 & .000 \\
\hline & & & 1 & -15.199 & 18.768 & .422 \\
\hline \multirow[t]{12}{*}{ switchgrass } & \multirow[t]{6}{*}{$0.3 \mathrm{~m}$} & \multirow[t]{2}{*}{0} & 1 & $-41.558\left(^{*}\right)$ & 18768 & .032 \\
\hline & & & 28 & $-120.494\left(^{*}\right)$ & 18.768 & .000 \\
\hline & & \multirow[t]{2}{*}{1} & 0 & $41.558\left(^{*}\right)$ & 18.768 & .032 \\
\hline & & & 28 & $-78.936\left(^{\star}\right)$ & 18.768 & .000 \\
\hline & & \multirow[t]{2}{*}{28} & 0 & $120.494\left(^{*}\right)$ & 18.768 & .000 \\
\hline & & & 1 & $78.936\left(^{*}\right)$ & 18.768 & .000 \\
\hline & \multirow[t]{6}{*}{$0.9 \mathrm{~m}$} & \multirow[t]{2}{*}{0} & 1 & $-197.191\left(^{*}\right)$ & 18.768 & .000 \\
\hline & & & 28 & $-130.904\left(^{\star}\right)$ & 18.768 & .000 \\
\hline & & \multirow[t]{2}{*}{1} & 0 & $\left.197.1911^{*}\right)$ & 18.768 & .000 \\
\hline & & & 28 & $66.287\left(^{\star}\right)$ & 18.768 & .001 \\
\hline & & \multirow[t]{2}{*}{28} & 0 & $130.904\left(^{\star}\right)$ & 18.768 & .000 \\
\hline & & & 1 & $-66.287\left(^{\star}\right)$ & 18.768 & .001 \\
\hline
\end{tabular}

Based on estimated marginal means

* The mean difference is significant at the .05 level.

a Adjustment for multiple comparisons: Least Significant Difference (equivalent to no adjustments). 
Table 17: Pairwise comparisons between days and treatments for distances 0.3 and $0.9 \mathrm{~m}$ for fungal count.

\begin{tabular}{|c|c|c|c|c|c|c|}
\hline Day & Cover & (I) Distance & (J) Distance & $\begin{array}{c}\text { Mean } \\
\text { Difference } \\
(1-J)\end{array}$ & Std. Error & Sig.(a) \\
\hline \multirow[t]{4}{*}{0} & \multirow[t]{2}{*}{ bare } & $0.3 \mathrm{~m}$ & $0.9 \mathrm{~m}$ & -.097 & 1.274 & 939 \\
\hline & & $0.9 \mathrm{~m}$ & $0.3 \mathrm{~m}$ & .097 & 1.274 & .939 \\
\hline & \multirow[t]{2}{*}{ switchgrass } & $0.3 \mathrm{~m}$ & $0.9 \mathrm{~m}$ & -.250 & 1.274 & 845 \\
\hline & & $0.9 \mathrm{~m}$ & $0.3 \mathrm{~m}$ & .250 & 1.274 & 845 \\
\hline \multirow[t]{4}{*}{1} & \multirow[t]{2}{*}{ bare } & $0.3 \mathrm{~m}$ & $0.9 \mathrm{~m}$ & -.958 & 1.274 & .456 \\
\hline & & $0.9 \mathrm{~m}$ & $0.3 \mathrm{~m}$ & .958 & 1.274 & .456 \\
\hline & \multirow[t]{2}{*}{ switchgrass } & $0.3 \mathrm{~m}$ & $0.9 \mathrm{~m}$ & .075 & 1.274 & 954 \\
\hline & & $0.9 \mathrm{~m}$ & $0.3 \mathrm{~m}$ & -.075 & 1.274 & .954 \\
\hline \multirow[t]{4}{*}{28} & \multirow[t]{2}{*}{ bare } & $0.3 \mathrm{~m}$ & $0.9 \mathrm{~m}$ & 1.793 & 1.274 & .166 \\
\hline & & $0.9 \mathrm{~m}$ & $0.3 \mathrm{~m}$ & -1.793 & 1.274 & 166 \\
\hline & \multirow[t]{2}{*}{ switchgrass } & $0.3 \mathrm{~m}$ & $0.9 \mathrm{~m}$ & $-5.437\left(^{\star}\right)$ & 1.274 & .000 \\
\hline & & $0.9 \mathrm{~m}$ & $0.3 \mathrm{~m}$ & $5.437\left(^{\star}\right)$ & 1.274 & .000 \\
\hline
\end{tabular}

Based on estimated marginal means

* The mean difference is significant at the 05 level.

a Adjustment for multiple comparisons: Least Significant Difference (equivalent to no adjustments),

Table 18: Pairwise comparisons between days and treatments for distances $0.3 \mathrm{~m}$ and 0.9 $\mathrm{m}$ for bacterial count.

\begin{tabular}{|c|c|c|c|c|c|c|}
\hline Day & Cover & (l) Distance & (J) Distance & $\begin{array}{c}\text { Mean } \\
\text { Difference } \\
(1-J)\end{array}$ & Std. Error & Sig.(a) \\
\hline \multirow[t]{4}{*}{0} & \multirow[t]{2}{*}{ bare } & $0.3 \mathrm{~m}$ & $0.9 \mathrm{~m}$ & $48.538\left(^{*}\right)$ & 18.768 & .013 \\
\hline & & $0.9 \mathrm{~m}$ & $0.3 \mathrm{~m}$ & $-48.538\left(^{*}\right)$ & 18.768 & .013 \\
\hline & \multirow[t]{2}{*}{ switchgrass } & $0.3 \mathrm{~m}$ & $0.9 \mathrm{~m}$ & $39.760\left(^{*}\right)$ & 18.768 & .039 \\
\hline & & $0.9 \mathrm{~m}$ & $0.3 \mathrm{~m}$ & $\left.-39.7600^{*}\right)$ & 18.768 & .039 \\
\hline \multirow[t]{4}{*}{1} & \multirow[t]{2}{*}{ bare } & $0.3 \mathrm{~m}$ & $0.9 \mathrm{~m}$ & $-55.901\left(^{\star}\right)$ & 18.768 & .005 \\
\hline & & $0.9 \mathrm{~m}$ & $0.3 \mathrm{~m}$ & $55.901\left(^{\star}\right)$ & 18.768 & .005 \\
\hline & \multirow[t]{2}{*}{ switchgrass } & $0.3 \mathrm{~m}$ & $0.9 \mathrm{~m}$ & $-115.874\left(^{*}\right)$ & 18.768 & .000 \\
\hline & & $0.9 \mathrm{~m}$ & $0.3 \mathrm{~m}$ & $115.874\left(^{*}\right)$ & 18.768 & .000 \\
\hline \multirow[t]{4}{*}{28} & \multirow[t]{2}{*}{ bare } & $0.3 \mathrm{~m}$ & $0.9 \mathrm{~m}$ & $60.022\left(^{*}\right)$ & 18.768 & .002 \\
\hline & & $0.9 \mathrm{~m}$ & $0.3 \mathrm{~m}$ & $-60.022\left(^{*}\right)$ & 18.768 & .002 \\
\hline & \multirow[t]{2}{*}{ switchgrass } & $0.3 \mathrm{~m}$ & $0.9 \mathrm{~m}$ & 29.349 & 18.768 & .124 \\
\hline & & $0.9 \mathrm{~m}$ & $0.3 \mathrm{~m}$ & -29.349 & 18.768 & .124 \\
\hline
\end{tabular}

Based on estimated marginal means

* The mean difference is significant at the 05 level.

a Adjustment for multiple comparisons: Least Significant Difference (equivalent to no adjustments) 


\section{LIST OF REFERENCES}

Agency for Toxic Substances and Disease Registry (ATSDR). Toxicological Profile for Endosulfan, update; US Department of Health and Human Services, 2000.

Alexander, Martin. Introduction to Soil Microbiology, $2^{\text {nd }}$ ed.; John Wiley \& Sons: New York, 1977; pp 16-35.

Ballschmitter, K.; Schophan, I.; Tölg, G. The metabolization of endosulfan in insects and mammals. Paper presented to the VI International Plant Protection Congress, Vienna, 1967.

Bardgett, Richard. The Biology of Soil: A Community and Ecosystem Approach; Oxford University Press: New York, 2005; pp 24-56.

Blanco-Canqui, H.; Gantzer, C. J.; Anderson, S. H.; Alberts, E. E.; Thompson, A. L. Grass barrier and vegetative filter strip effectiveness in reducing runoff, sediment, nitrogen, and phosphorus loss. Soil Science Society of America Journal. 2005, 68, $1670-1678$.

Boyer, A. Reducing Bacteria with Best Management Practices. Delaware Department of Natural Resources and Environmental Control, Watershed Assessment Section, 2006. Accessed online August 2006 at http://www.wr.udel.edu/ChristinaTribTeam/Fact $\% 20$ Sheets/ReducingBacteria_w BMPs.pdf

Buttler, T.; Martinkovic, W.; Nesheim, O.N. Factors Influencing Pesticide Movement to Ground Water. Florida Cooperative Extension Service, Institute of Food and Agricultural Sciences, University of Florida, 2003.

Extension Toxicology Network (EXTOXNET). Pesticide Information Profiles:

Endosulfan. A Pesticide Information Project of Cooperative Extension Offices of Cornell University, Oregon State University, the University of Idaho, and the University of California at Davis and the Institute for Environmental Toxicology, Michigan State University, 1996. Accessed online May 2006 at http://extoxnet.orst.edu/pips/endosulf.htm

Hapeman, C.J.; Rice, C.; McConnel, L.L.; Schmidt, W. Atmospheric Processes of Agricultural Pollutants That Affect Air and Water Quality: 2002 Annual Report. ARS Project, Environmental Management and Byproduct Utilization Laboratory. 2002. Project No. 1265-12220-003-00.

Harman Fetcho, J.A.; Mcconnell, L.L.; Potter, T.L.; Rice, C.; Sadeghi, A.M.; Sefton, K.A.; Schaffer, B.A.; Curry, R.W.; Bialek Kalinski, K.M.; Smith, R.D.; Hapeman, C.J. Pesticide occurrence in selected South Florida canals and Biscayne 
Bay during high agricultural activity. Journal of Agriculture and Food Chemistry. 2005, 53 (15), 6040-6048.

International IUPAC Congress of Pesticide Chemistry, 2d, Tel-Aviv, 1971; Fate of Pesticides in Environment; Proceedings; Tahori, A. S., Ed.; Gordon and Breach: New York, 1972; pp 283-292.

Joseph, R.; Reed, S.; Clark-Cuadrado, C; Jayachandran, K. Effects of endosulfan on soil respiration. Presented at ASA-CSSA-SSSA Annual Meetings, New Orleans, LA, November 4-8, 2007; 448.

Kegley, S.; Hill, B.; Orme, S. PAN Pesticide Database, Pesticide Action Network, North America: San Francisco, CA., 2007. Accessible online at http://www.pesticideinfo.org.

Kumar K.; Devi, S.S.; Krishnamurthi, K.; Kanade, G.S.; Chakrabarti, T. Enrichment and isolation of endosulfan degrading and detoxifying bacteria. Chemosphere. 2006, 68 (2), 317-322.

Kwon, G-S.; Sohn H-Y.;Shin, K-S.; Kim, E.; Seo, B-I. Biodegradation of the organochlorine insecticide, endosulfan, and the toxic metabolite, endosulfan sulfate, by Klebsiella oxytoca KE-8. Applied Microbiology and Biotechnology. $\mathbf{2 0 0 5}, 67(6), 845-850$.

Landon, M.; Jacobsen, J.; Johnson, G. Pesticide Management for Water Quality Protection; Montana State University Extension Service, 1994.

Lee, K-H.; Isenhart, T.M.; Schultz, R.C.; Mickelson, S.K. Nutrient and sediment removal by switchgrass and cool-season grass filter strips in Central Iowa, USA. Agroforestry Systems. 1998, 44 (2, 3), 121-132.

Mersie, W.; Seybold, C. A.; and McNamee, C.; Lawson, M.A. Comparison of switchgrass and tall fescue filter strips for abating endosulfan runoff moving at two different flow rates. Agriculture, Ecosystems, and Environment, 2005, under review.

Moriarty, F. Ed. Organochlorine Insecticides : Persistent Organic Pollutants; Academic Press: New York, 1975; pp 1-15.

Pesticide Action Network of North America (PANNA). Summary of the Proposal for listing Endosulfan in the Stockholm Convention on Persistent Organic Pollutants, 2007. Accessed online August 2007 at http://www.panna.org/resources/documents/endosulfanProposalStockholm.pdf 
Pietikäinen, J.; Pettersson, M.; Bååth, E. Comparison of temperature effects on soil respiration and bacterial and fungal growth rates. Federation of European Microbiological Societies (FEMS) Microbiology Ecology. 2005, 52 (1), 49-58.

Rao, P.S.C.; Mansell, R.; Baldwin, L.B.; Laurent, M.F. Pesticides and their behavior in soil and water; Florida Cooperative Extension Service, Institute of Food and Agricultural Sciences; University of Florida, 2006.

Schultz, R.C.; Isenhart, T.M.; Colletti, J.P. Riparian Buffer Systems in Crop and Rangelands. Agroforestry and Sustainable Systems: Symposium Proceedings. USDA Forest Service General Technical Report RM-GTR-261, 1995. pp 13-27.

Siddique, T.; Zahir, Z.A.; Frankenberger, W.T. Reversed-Phase Liquid Chromatographic Method for Analysis of Endosulfan and Its Major Metabolites. Journal of Liquid Chromatography \& Related Technologies. 2003, 26 (7), 1069-1082.

Soil and Plant Analysis Council. Soil analysis handbook of reference methods. CRC Press, Washington, DC, 1999.

Sparling, D.W.; Fellers, G. Comparative toxicity of chlorpyrifos, diazinon, malathion and their oxon derivatives to larval Rana boylii. Environmental Pollution. 2007, 147 (3), 535-539.

Staddon, W. J.; Locke M. A.; Zablotowicz, R. M. Microbiological Characteristics of a Vegetative Buffer Strip Soil and Degradation and Sorption of Metolachlor. Soil Science Society of America Journal. 2001, 65, 1136-1142.

Sutherland, T.D.; Horne, I.; Lacey, M.J.; Harcourt, R.L.; Russell, R.J.; Oakeshott, J.G. Enrichment of an Endosulfan-Degrading Mixed Bacterial Culture. Applied and Environmental Microbiology. 2000, 66 (7), 2822-2828.

Tugel, A.; Lewandowski, A.; Happe-vonArb, D. Soil Biology Primer, Rev. Ed. Ankeny. Soil and Water Conservation Society, lowa, 2000.

U.N. Environmental Program (UNEP). Global Environmental Outlook 2000. Earthscan Publications: London, 2000.

U.S. Department of Agriculture (USDA). Plant Material Fact Sheet.. Natural Resources Conservation Service, Plant Material Programs. 1999. Accessed online May 2006 at http:/plant-materials.nrcs.usda.gov/pubs/txpmsbrbffstrp332.pdf

U.S. Department of Agriculture (USDA). Plant Fact Sheet: Switchgrass. Natural Resources Conservation Service. 2001. Accessed online May 2006 at http://www.plants.usda.gov/factsheet/pdf/fs pavi2.pdf

U.S. Department of Agriculture (USDA). Conservation Buffers to Reduce Pesticide Losses. Natural Resources Conservation Service (NRCS): Washington DC, 2002. 
U.S. Department of Agriculture, National Agricultural Statistics Service (NASS). 2002 Census of Agriculture. Florida County Level Data. Accessed online on May 2006 at http://www.agcensus.usda.gov.

U.S. Department of the Interior. Endosulfan Insecticide 2002 Estimated Annual Agricultural Use. National Water Quality Assessment Program Pesticide National Synthesis Project, 2002. Accessed online October 2006 at http://ca.water.usgs.gov/pnsp/pesticide_use_maps/

U.S. Environmental Protection Agency (EPA). National Water Quality Inventory: 1990 Report to Congress. Office of Water, EPA, 503/9-92/006, August 1992.

U.S. Environmental Protection Agency (EPA). Reregistration eligibility decision for endosulfan. Office of Prevention, Pesticides and Toxic Substances (OPPTS) EPA 738-R-02-013, 2002. Accessed online August 2006 at http://www.epa.gov/oppsrrd1/REDs/endosulfan_red.pdf.

U.S. Environmental Protection Agency (EPA). 2007. ECOTOX User Guide: ECOTOXicology Database System. Version 4.0. Available online at: http:/www.epa.gov/ecotox/search for endosulfan.

Wood, Martin. Soil Biology. Chapman and Hall: New York, 1989; pp 7-24.

Wright, R.J.; Witkowski, J.F.; Schulze, L.D. Water Resource Management: Water Quality. NebGuide. Institute of Agriculture and Natural resources, University of Nebraska, 1993. 